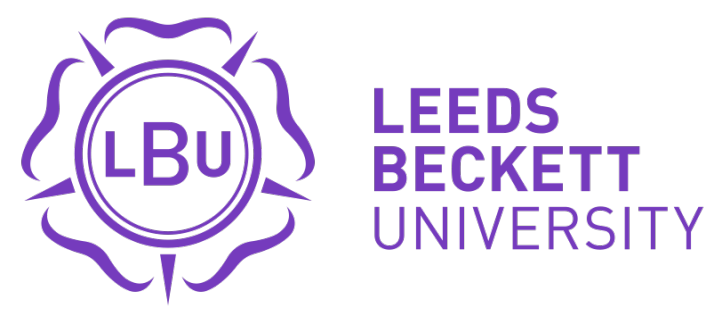

Citation:

Asiyanbola, OA and El Khantouti, I and Akinwale, A and Ahenkora-Duodu, $\mathrm{K}$ and Imam, R and Toukebri, R and Mohanty, J (2021) An Analytical Outlook of the Commercial Space Industry for the Last Frontier: Potential Entrepreneurial Evaluation of the African Space Sector. New Space, 9 (3). pp. 169-186. ISSN 2168-0256 DOI: https://doi.org/10.1089/space.2020.0016

Link to Leeds Beckett Repository record:

https://eprints.leedsbeckett.ac.uk/id/eprint/8301/

Document Version:

Article (Published Version)

Creative Commons: Attribution 4.0

The aim of the Leeds Beckett Repository is to provide open access to our research, as required by funder policies and permitted by publishers and copyright law.

The Leeds Beckett repository holds a wide range of publications, each of which has been checked for copyright and the relevant embargo period has been applied by the Research Services team.

We operate on a standard take-down policy. If you are the author or publisher of an output and you would like it removed from the repository, please contact us and we will investigate on a case-by-case basis.

Each thesis in the repository has been cleared where necessary by the author for third party copyright. If you would like a thesis to be removed from the repository or believe there is an issue with copyright, please contact us on openaccess@leedsbeckett.ac.uk and we will investigate on a case-by-case basis. 


\section{An Analytical Outlook of the Commercial Space Industry for the Last Frontier: Potential Entrepreneurial Evaluation of the African Space Sector}

Oyedamola A. Asiyanbola, ${ }^{1-3, *}$ Imane El Khantouti, ${ }^{2-4}$ Abraham Akinwale, ${ }^{2, \dagger}$ Kingsley Ahenkora-Duodu, ${ }^{2,5,4}$ Rayan Imam, ${ }^{2,6}$ Rania Toukebri, ${ }^{2}$ and Joshit Mohanty ${ }^{1, \S}$

${ }^{1}$ Skolkovo Institute of Science and Technology, Moscow, Russia Federation.

${ }^{2}$ Space Generation Advisory Council (SGAC), Vienna, Austria.

${ }^{3}$ Commercial Space Project Group of the Space Generation Advisory Council (CSPG, SGAC).

${ }^{4}$ Université Grenoble Alpes (UGA), Grenoble, France.

${ }^{5}$ School of Physics and Astronomy, University of Leeds, Leeds LS2 9JT, UK.

${ }^{6}$ Politecnico di Torino, Department of Electronics and Telecommunications, Turin, Italy.

*ORCID ID (https://orcid.org/0000-0002-9793-6723).

${ }^{\dagger}$ ORCID ID (https://orcid.org/0000-0003-0017-0424).

*ORCID ID (https://orcid.org/0000-0002-4453-7120).

${ }^{\S}$ ORCID ID (https://orcid.org/0000-0003-1078-0314).

\section{ABSTRACT}

The African continent is growing at a fast pace, and its economic pulse has heightened. However, there is a growing momentum within the community of researchers, businesses, and investors to make an overall survey and assessment of progress sustained in the African space industries as a whole. There is no debate on the fact that documentation is pivotal to every research progress. Thus far, poor documentation has been inimical to the growth of the African economy and also the African space industry. In collaborative efforts with the African Space Generation Advisory Council (SGAC) body, this article is an attempt at documenting progress, and it includes the analysis of the entrepreneurial outlook of some selected countries (Nigeria, Ghana, Morocco, Mauritius, Sudan, and Tunisia) in Africa. This study aims at sustaining the African economic drive by using a multimethod approach involving Gynawali and Fogel's "key dimensions of environments for entrepreneurship development," to understand the economic environment in those nations while incorporating the versatile national competitive advantage diamond model of Michael Porter. Comparisons can be drawn between African countries and member nations in BRICS (Brazil, Russia, India, China, and South Africa) to obtain a conclusion toward fueling the increasing space science and technological drive in Africa. Research is essential for industries and socioeconomic development in Africa-the Last Frontier, which remains a potential ground for global commercial space growth.

Keywords: target market assessment, African Space Agency (ASA), competitive advantage

\section{INTRODUCTION}

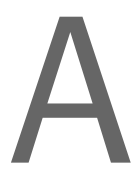

frica-a continent, is home to more than 50 countries. It is a far-cry to be exact on the number of countries in the continent owing to the political atmosphere in some of the nations that could lead to the creation of new states. The aim of every government, however, is to strengthen and make focused economic policies that will aid rapid development with an objective toward economic convergence. ${ }^{1,2}$ Aside from the political unrest in some of these countries domiciled in Africa, African countries form the most significant percentage of the growing and emerging economies in the world. ${ }^{3}$ This statement as a fact makes Africa the destination for foreign investments from the more Advanced Nations in the world. Africa is truly the "Last Frontier"-an expanse of land (30.37 million sq. km) with countries ascribed developing economies due to their level of technological growth and a large volume of untapped potential. Another vital point to note is that most of the countries in Africa are the neutral, nonaligned nations with portends for political stability thereby allowing for a free market economy where the forces of demand and supply are primarily sovereign. ${ }^{4,5}$ 
Many of the countries in Africa are making new strives to keep a current view of "Launching Space Research and Development toward innovation and creation of new business ventures." The theme for the second Space Generation Advisory Council (SGAC) Workshop, 2018, held at Port Louis, Mauritius, had an incline toward "Launching Space Exploration in Africa" following the first SGAC workshop in Akure, Nigeria. This new trend and development from the discussions at the last two series of the Space Generation Advisory Council Workshop (SGW), Space Leadership conference space events, Global Conference on Space for Emerging Countries (GLEC) among space sector stakeholders have brought about means toward collaborative efforts between SGAC member countries in Africa. In collaborative efforts with the African-SGAC body, this article aims at documenting progress made in the space sector of these selected countries: Nigeria, Ghana, Morocco, Mauritius, and Sudan (NGMMS) in Africa. Moreover, it also includes an overview analysis of the entrepreneurial outlook of selected countries. Africa is seen as "the Last Frontier" for global economic growth. Since the noticed economic transformation seen in the member countries of BRICS (Brazil, Russia, India, China, and South Africa), analysts including observers have regarded Africa as the "New Frontier" instead-a continent of raw potential yet ripened for wealth creation and expansion. From possibilities to render services to other space agencies outside Africa, providing grounds for lunch pads, and simulation of extraterrestrial beds.

\section{METHODOLOGY AND DATA}

As a case study, the conjoined ideologies of both Gynawali and Fogel's (GCtF) critical dimensions of environments for entrepreneurship development portal stages of competitive advantage were taken into consideration. ${ }^{6-8}$ The G\&F method was earlier used for Japan's entrepreneurial environment analysis by Challotte Kiang. ${ }^{7}$ The Porter diamond model pioneered by the economist Michael Porter was used to weigh the competitive advantage of studied African countries by assessing the following:

- Space agencies in the selected countries.

- Space policy and interest (aspect of space REtD, applications of interest to each country).

- Partnerships with foreign bodies (countries).

- Challenges, successes, strives, development.

- Potential still lying fallow.

- Investment streams.

- Progress of the private industries and emergence of thriving start-ups.

- Education programs and partnerships that have or would bring the countries to the forefront of space development.
A multimethod approach was implemented to study the space sector of these countries, taking into consideration the scarcity of documented scholarly articles on the chosen countries; on countries such as South Africa and Nigeria, we found some case studies. ${ }^{9,10}$ Resources such as blogs, websites, and presentations from series of meetings, workshops, and conferences were evaluated. A range of data analysis was performed using opensource data from the World Bank on several economic markers such as gross domestic product (GDP), foreign direct investment (FDI), and the academic publications to evaluate general research funding for education in the African countries understudied. To understand if a range of growing professionals in the technical field know of the GCtF and Michael Portal stages of development, questionnaires were prepared to assess the awareness and need for growth in the African space industry. General perspectives were obtained from selected participants of GLEC. A selected group of young professionals within the SGAC community, also given that most of the authors are National Point of Contact under SGAC (NPoCs) of their countries; contacts were made personally on a professional basis to those in the growing private space sector in Africa. Especially from those dealing with the emerging space application ventures, with the sole aim to get current perspectives of the African space sector.

\section{Level of Analysis}

The reports under the auspices of the study group "Public/ Private Human Access to Space" also known as the Human Orbital Market (HOM) study group commissioned by the International Academy of Astronautics (IAA) developed the framework for the identification and analysis of relevant factors that support a global HOM, which is expected to be conducted at a worldwide scale. ${ }^{1-13}$ The phases were formulated based on the factors that support global human orbital spaceflight market. The elements are the political, legal, capital, historical, and cultural factors. The HOM cosmic study outlined five phases for more in-depth analysis on a national level. ${ }^{11}$ By utilizing the framework proposed by the HOM, we performed to a large extent the first three phases of analysis for the selected African countries of interest. The outcome of this study is expected to assist the policy formulation and implementation of the African Space Agency (ASA).

According to the assertions of the Michael Porter's theory, there are four stages of competitive development based on each nation's source of advantage (Portal diamond components): they are, the factor-driven stage, investment-driven stage, innovation-driven stage, and the wealth-driven stage. ${ }^{8}$ There are many variants summarized in the Portal diamond components from the nation's policy structure and economic strategies. At the factor-driven stage, the average standard of 
living is low as the nations derive their competitive advantage from the proceeds of internal trade of the endowed natural resources (which are grossly underutilized).

Nations at the investment-driven stage show readiness to increase their productivity through investment in infrastructural development, usually imported technology. Moreover, with returns from the trade of their natural resources (factor outputs), often as exports to foreign nations, they can drive a rise in the standard of living. Competitive advantage at this stage is due to the production efficiencies, performance improvement in the nation's factor-driven outputs. For countries in the innovation-driven stage, they improve on the foreign supplied technologies. Nations at this stage invest more in their educational sector and research and development. This aids them in the creation of a new range of value-propositions. These value-propositions give a boost to their competitive advantage; they indigenously grow intellectual property and can maximize the use of factors of production. Based on the HOM framework, the first three stages have their definitions ingrained on the progression of the nation's productive capacity and increasing degrees of competitiveness. ${ }^{11}$ The last stage on wealth-driven propensity of the nation is founded on the bases of the counties' ease of doing business, sophistication of the capital market, swiftness in policymaking and implementation, utmost regard for the rule of law, national economic market sensitivity to drive creation of wealth from the output of increasing innovation excellence, and this is due to the high educational level and robust RED sector that allow creation of the requirements for global commercialization and economic growth. The United States has graduated through the first three stages over the years and currently in transition to the last stage of competitiveness. ${ }^{1-13}$ Based on the knowledge of the Porter stages, Table 1 shows countries of BRICS and the selected countries (NGMMS and Tunisia) that can also be placed reasonably in the respective categories. One assumption taken here was that countries with a GDP less than $\$ 15$ trillion are yet in transition (T) to the wealth driven, but entirely in (I) one of the Porter's stages.

Based on the current trends, both Russia and China are of similitudes to the United States in terms of their innovation propensity, and it can be argued that they are not only driving their innovation but also working tirelessly for assuming the competitive wealth-driven stage. ${ }^{14,15}$ Brazil like Nigeria, South Africa, and Ghana is also transitioning from the investment-stage to the innovation-driven stages. India, however, has indeed taken the world by storm and is entirely in the innovation-driven stage. More details on this are discussed in the following section on assessing and drawing a comparison between the economic stance and the space RED of India with the selected African countries.

\begin{tabular}{|c|c|c|c|}
\hline & $\begin{array}{l}\text { Investment- } \\
\text { Driven Stage }\end{array}$ & $\begin{array}{l}\text { Innovation- } \\
\text { Driven Stage }\end{array}$ & $\begin{array}{c}\text { Wealth- } \\
\text { Driven Stage }\end{array}$ \\
\hline Brazil & T & T & \\
\hline Russia & & I & T \\
\hline India & & 1 & \\
\hline China & & T & T \\
\hline South Africa & $\mathrm{T}$ & T & \\
\hline Nigeria & T & T & \\
\hline Ghana & I & & \\
\hline Morocco & 1 & & \\
\hline Mauritius & 1 & & \\
\hline Sudan & I & & \\
\hline Tunisia & I & & \\
\hline
\end{tabular}

$\mathrm{I}$, solely at the given stage; $\mathrm{T}$, countries showing transition.

\section{ASSESSING THE SPACE SECTORS OF THE SELECTED COUNTRIES USING G\&F KEY DIMENSIONS OF ENVIRONMENTS FOR ENTREPRENEURSHIP DEVELOPMENT}

To understand the economic strength of the countries selected for the analysis, we assumed that the space market of these countries would have proportionate correlation with their GDP. Figure 1 shows the GDP trends of BRICS and several African countries with the potential to be a part of an ASA. The African countries whose GDP was summed up to form the GDP of ASA countries are countries that are part of the United Nations Office for Outer Space Affairs (UNOOSA) which supersees the peaceful uses of Outer Space. There are four distinct curves in Figure 1 to see the GDP contribution effect of South Africa and India toward the economic strength of BRICS. The ASA has much work to do, if the earlier space market-GDP assumption is correct. Hence, the need for entrepreneurial assessment of the Last Frontier (Africa).

\section{Nigeria}

According to the latest report of the World Population Review, Nigeria is currently the largest country by population in the African continent, with over 200 million people. ${ }^{16-18}$ Over 180 million of the entire population of the country are youths who are younger than 30 years, with $82 \%$ of these youths looking into one entrepreneurship opportunity or the other. ${ }^{19,20}$ The Nigerian economy GDP is expected to grow from $2.3 \%$ in 2019 to $2.5 \%$ in 2020 , and the country is 


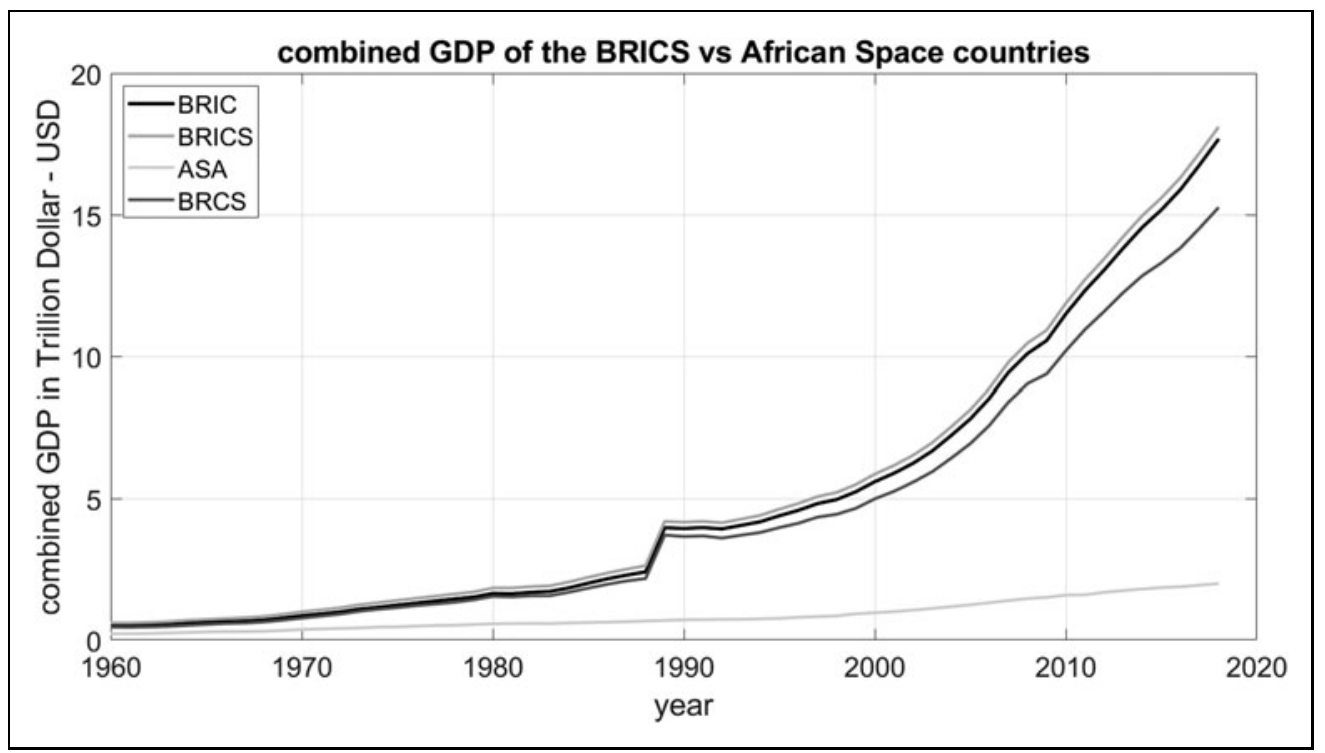

Fig. 1. Combined GDP of BRIC, BRICS, and space faring countries in Africa. GDP, gross domestic product; BRCS, combined GDP of these respective countries (Brazil, Russia, China and South Africa); BRIC, combined GDP of these respective countries (Brazil, Russia, India and China); BRICS, Brazil, Russia, India, China, and South Africa.

expected to have more diversity in the economic structure with more focus on other sectors than the dominating oil sector of the country. ${ }^{20}$ Nigerian youths are gradually developing more start-ups in the technology sector, which is one of the primary focuses of the new economy. ${ }^{21}$

There has been significant growth in technology companies in Nigeria with the sector raising over 178 million U.S. dollars in 2018. ${ }^{14}$ According to the latest report by the IntelPoint, Google gave out 2,000,000 (million) U.S. dollars to the kickoff African Edition of the Google Impact Challenge. More insight into the report showed that 90 investors were able to invest in these 148 start-up companies, and these lists are increasing even for the year 2019. ${ }^{14}$ These statistics showed that the technology companies in Nigeria are doing a lot varying from backend programming to payment platforms, software development, robotics, internet of things, artificial intelligence, and many more, which are very much spinoffs of space exploration and commercial markets.

One other primary sector of space development is the education sector; Nigerian universities are proliferating technology-wise with specific highlights to prove that. The African Centre of Excellence by the World Bank is one of the major leading programs leading to technology growth in Nigeria. ${ }^{22}$ The Obafemi Awolowo University, with the award of 8 million dollars, has been able to build the first Knowledge Park in the whole country with leading Information Communication Technology centers to help students, start-ups, and further promote research. Other universities in the country such as the Federal University of Agriculture, Abeokuta (Centre for Agricultural Development and Sustainable EnvironmentCEADESE), Redeemer's University, Ede (Centre of Excellence for Genomics of Infectious Diseases-ACEGID), University of Jos, University of Benin, and University of Port-Harcourt are all centers relating to medicine and oil field chemicals, and have also benefited from these activities. ${ }^{22-24}$

Over the past couple of years, technology growth in the Nigerian economy from the industry, the space agency of the country, and the educational impact has motivated the young minds of the country toward many space projects and outreach programs. Nonprofit organizations such as the SGAC, the African Regional Centre for Space Science and Technology Education in English (ARCSSTE-E), the Space Club Obafemi Awolowo University have contributed immensely to space outreach workshops, training all around the country. ${ }^{25-27}$

The Federal Ministry of Science and Technology of the Nigerian Government has tasked the National Space Research and Development Agency (NASRDA) to oversee space activities within the country. ${ }^{28-31}$ With the task given to the agency since 1999, it has been able to dominate satellite launches in the continent with 10 satellite launches so far, space policies, and space operations within the country. ${ }^{28,29}$ The center is well diversified and operates through its various subcenters around the country. ${ }^{29,31}$ These centers oversee primary space operations within the country, and they are the primary focus of jobs and application for space experts within the country; these centers include the following:

- The Centre for Basic Space Science (CBSS): The center oversees research and development in the space environment. $^{32}$

- The Centre for Satellite Technology Development (CSTD): This center oversees the satellite manufacturing and other major space-based manufacturing structures. ${ }^{32}$

- The Centre for Atmospheric Research (CAR): The center oversees atmospheric research parameters through its ground stations and provides $24 \mathrm{~h}$ of atmospheric data for agencies, research students, and institutions needing 
them. ${ }^{33-36}$ It is the first agency to deploy the first atmospheric weather profiling Unmanned Aerial vehicles with the support of MPG Aerospace Ltd. ${ }^{36}$

- The Centre for Space Science and Technology Education (CSSTE) is also called the ARCSSTE-E ${ }^{27,35}$ : This center oversees space outreach programs under the canopy of NASRDA and coordinates efforts with the various institutions to educate the public about space exploration and other space activities.

- Centre for Geodesy and Geodynamics: This center oversees research and development in crustal movements. ${ }^{37,30}$

- National Centre for Remote Sensing: The center oversees earth observation and remote sensing.

The Nigerian Government has been able to partner with several countries overtime for its satellite productions and launches. The NigerianSat-1 was built by the Surrey Space Technology Limited, a United Kingdom-based satellite company, and it was launched in Russia, and several other Nigerian satellites have been built by China and also launched by China. The NigComSat-1 was a Nigerian communication satellite that was built and launched by China and was replaced by the NigComSat-2, NigComSat-3, and NigComSat-X. ${ }^{38}$

Nigeria as a country has faced major challenges with regard to space policies and indigenous technology growth and promotions, funding for space projects, start-up incubations, investors, and accessibility to affordable quality materials for research productions. ${ }^{39}$ Nevertheless, despite these challenges, some companies such as Andela, Interswitch, and TeamApt are growing and providing more paths for start-ups to thrive in the space economy. ${ }^{40}$ The offsets of the new space idea have given rise to entrepreneurs to succeed more in the commercial space sector of space. There is more demand for earth observation equipment, and more threats in the northern region with regard to the herdsmen/farmer clashes and insurgencies and many more security challenges are more open ways for aerial surveillance, satellite navigation systems, remote sensing, low latency communication services, and many more. ${ }^{41,42}$ Now is the perfect timing for new space commercial activities in the country. ${ }^{43}$ We have the market (in terms of the people), and every venture capitalist investing has vast prospects of profits with proper scaling of the businesses. The commercial space sector contributes $75 \%$ of the entire global space economy with the satellite servicing companies dominating most of these revenues. ${ }^{44}$ The national telecommunication market is still a massive market for spin-off companies to thrive. Start-ups and companies with proper business plans calculated their earned market value, the internal return rate, and getting their business canvas in place for public and private investment.
India

The Indian Space Research Organisation (ISRO) emerged as not only a stand-alone space decision-making body of India, but it also paved the way for the growth of private industries within the territory. From the initial days of focusing on remote sensing and communication satellites to RISAT-2B (also known as "eye in the sky"), advance RADAR satellite, ISRO has amended its objectives and work process. Everything needs to be changed so as the goals and policies. For sustainability, it is highly necessary to have incremental growth. India's rising space sector is not an exception either. In 2007, the then Chair of ISR0, Madhavan Nair, realized India had become self-stable to go beyond just public launches ${ }^{45}$ and focus on space exploration and profit-making institutions for the country. Following the days, ISR0 marked the robotic launches to the Moon and Mars. This has helped India to emerge as a Space State. ${ }^{46,47}$ Table 2 shows the planned ISR0's mission for the upcoming cycle. Starting from interspace missions to the first human spaceflight mission, ISRO is all set to begin its space endeavor by collaborating with private space players within the Indian subcontinent. ${ }^{48}$

Budget allocation to ISR0 never had a straight declaration. Budget estimate (BE) never suffixes the mission requirements at the end of the day going by cost-cutting and minimalistic expenditure of the Indian space agency. Almost every year, ISRO faces a revised estimate to fulfill the hard cash in the account. The total budget allocated takes up a share in each of the following: establishment expenditure, space technology,

Table 2. Indian Space Research Organisation Mission
Plans 2020
\begin{tabular}{l|c|c|c|c|c} 
Missions & $\mathbf{2 0 1 7 - 1 8}$ & $\mathbf{2 0 1 8 - 1 9}$ & $\mathbf{2 0 1 9 - 2 0}$ & $\mathbf{2 0 2 0 - 2 1}$ \\
\hline Earth observation satellites & 3 & 3 & 9 & 10 \\
\hline Communication satellites & 4 & 4 & 3 & 4 \\
\hline Navigation satellites & 2 & 1 & 0 & 2 \\
\hline Space science satellites & 0 & 0 & 2 & 1 \\
\hline Technology demonstration & 0 & 1 & 1 & 1 \\
\hline PSLV & 4 & 6 & 9 & 10 \\
\hline GSLV MK II & 2 & 1 & 2 & 3 \\
\hline GSLV MK III & 1 & 1 & 3 & 4 \\
\hline Small satellite launch vehicle & 0 & 0 & 3 & 2 \\
\hline Gaganyaan & 0 & 0 & 0 & 1 \\
\hline
\end{tabular}


space applications, space sciences, INSAT satellite systems, and miscellaneous expenditures. Space technology mugs up more than half of the total budget.

Figure 2 shows that the budget profile and the total BE for the financial year 2018-19 were $\$ 1,620.897$ million, and the total revised estimate was $\$ 1,683.514$ million. For the year 2019-20, the BE was declared to be $\$ 1,734.359$ million. The budget distribution over the years has been presented above. The budget is insignificant when weighed against other space agencies such as the NASA. However, it is a proud moment for the country when the space agency completes the endeavors even without a proper cash flow. Exclusive facilities are created at The ISRO Propulsion Complex (IPRC) for the PS2 and PS4 stages and engine integration through the Government-Owned and Company Operate (GOCO) model.

In 2018, the Government of India passed the Space Activities Bill, which was a boost to private space in the country. With the advent of new ventures such as the New Space India
Limited (NSIL) and Defence Space and Research Agency (DSRA), India sought to make its root stronger, yet diversified. The consequence-some notable space start-ups in the ecosystem. Currently, more than 10 significant start-ups are being active in this arena and they look forward to foreseeing beyond the traditional work culture. The focus is on the unused space potential and unlocking the new application for existing space info. These include the likes of Exseed Space, Bellatrix, Rocketeers, Society for Space Education Research and Development (SSERD), and AgniKul.

Rocketeers have pushed the space interest beyond the small community with its DIY steps and encouraging the students to take interest. ${ }^{49,50}$ Bellatrix got successful investment for its satellite propulsion and AgniKul raised \$30 million in seed funding. ${ }^{51,52}$ A significant part of these cash flows is from nonspace sectors, which shows the rising interest of the general public in space activities. Exseed Space became the first private body to manufacture satellite to be launched in Falcon Heavy of SpaceX.53,54

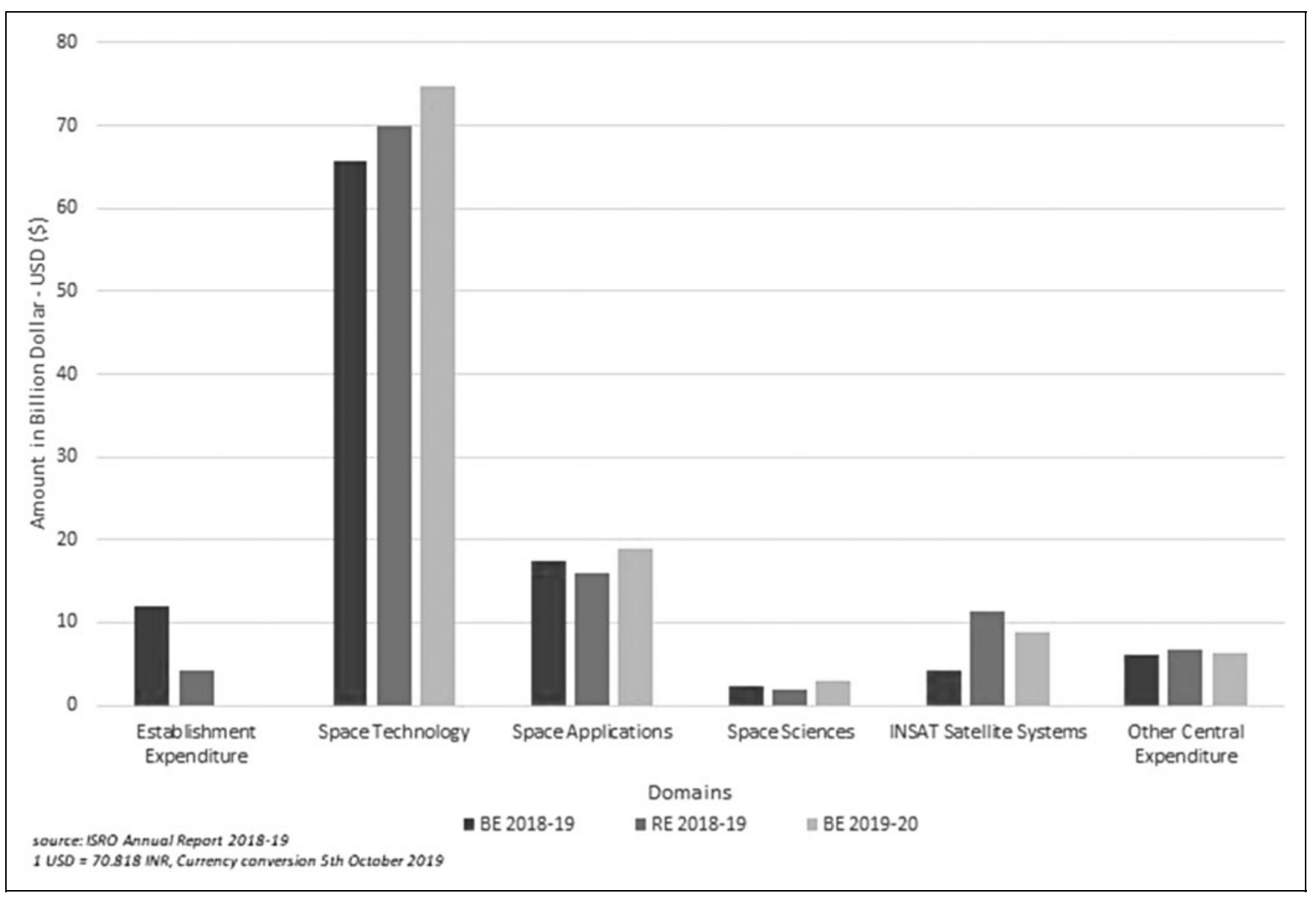

Fig. 2. ISRO budget profile. ISRO, Indian Space Research Organisation. 
To encourage a broad sphere of people involved in new space development, the Government of India (Space) has welcomed the suggestion and new experimental ideas of ISRO's innovative and first of its kind fourth nonrecoverable stage for orbital research. Exseed Space marked the achievement of the fastest manufacturing of satellite with minimalistic power required for ISRO's fourth stage experimental platform. This has inculcated interest in the youth to think interdisciplinary. ${ }^{55}$

Paving the way for new private players for space applications and market competencies, ISRO itself will focus on indepth space research such as the Chandrayan 2. It also aims to work closely with DRSA and DoS toward space force. ${ }^{56,57}$ Drawing an analogy to the collaborative work of DAPRA and NASA, DRSA and ISRO jointly will put forward India on the frontier. ${ }^{58}$ Apart from helping the new private buddies within the territory, ISRO also helps in technology transfer from overseas. As a result, an Indian start-up, Team Indus, enjoying the privilege of engineering one of NASA's rover to the Moon and Mars. ${ }^{59}$

Private competition in India is gearing up, and the community expects a lot to emerge. The government in its effort assisted more start-ups with tax relief schemes for the initial 5 years. The government body, the Ministry of Micro, Small and Medium Enterprises (MSME), has pushed the race even further by providing technical assistance to the growing companies. ${ }^{60,61}$ With the next generation coming in and space getting popularized among the parents, there has been a surge in the number of institutions providing space or aerospace engineering degree to students. Many renowned and premier institutes such as the Indian Institutes of technologies (Kanpur, Bombay, Madras) provide degrees in engineering, and scientific research in the premises of the Indian Institute of Space Science and Technology (IIST), Indian Institute of Astrophysics (IIA), Indian Institute of Science Education and Research (IISER), Inter-University Centre for Astronomy and Astrophysics (IUCAA), to name a few. Around 10,000 students graduate each year in aerospace/aeronautical engineering in India and the number rising by $(\sim 6 \%)$ yearly. After graduation, they are involved in either BPOs or ISRO subspace systems and contribute to the growing demand for space missions.

\section{Morocco}

Morocco with its strategic position on the map has always been a melting pot due to its diversity and a central crossroad international trading, since the foundation of the Phoenicians creating trading posts in Morocco ${ }^{62}$ to the gold-trade-route city of Sijilmassa in the middle ages ${ }^{63}$ and the multiple trading ports throughout the history of the kingdom. It remains, currently, a major destination for international industries. The economy of the country is a liberal economy with a supply and demand economic model. It is the 5th largest economy of Africa and was in 2017, the 57th widest economy worldwide by GDP purchasing power parity. ${ }^{64}$ The major sectors of that economy are tourism, agriculture, textile, aerospace, automotive, phosphates, and subcomponents. The key export partners are Spain $23.2 \%$, France $22.6 \%$, Italy $4.5 \%$, and the United States $4.2 \%$ (2017). $^{64}$

Due to the country's low-cost labor (327\$/month of wage), ${ }^{65}$ political stability, proximity to Europe, being a part of the Middle East and North Africa (MENA) region, as well as the availability of qualified subcontractors and local investment capital, the aerospace industry is skyrocketing. More than 130 aeronautics companies have settled in the country since 2001, including Safran, Bombardier, Boeing, and some Airbus subcompanies. In 2016, the industry minister stated that the aerospace market of Morocco had been multiplied by six during the last decade. ${ }^{66}$ By 2020, Boeing aims to create an ecosystem of suppliers that would double the aerospace sector of the kingdom. ${ }^{67}$ According to the FDI report on the aerospace cities of the future of 2016/2017, Casablanca, Morocco's economic capital, is ranked the 15th aerospace city worldwide overall of the future. ${ }^{68}$

Entrepreneurship in Morocco. According to 2019 "doing business report," Morocco is ranked 60th worldwide, second in the MENA region, ${ }^{69}$ and third among the African countries. ${ }^{70}$ Morocco is continually working on improving the creation of a business to diminish the number of procedures to follow and ease the formalities. The government is presently modernizing the aspects of entrepreneurship by organizing and sponsoring conferences and workshops, giving funding to young entrepreneurs, banking services, and loaning microenterprises. On the contrary, there exist diverse organizations all over the kingdom supporting entrepreneurship by helping in the creation and development of start-ups, mentoring the entrepreneurs, and looking for investors. Multiple technology start-ups were formed, thanks to the incubators, ecosystem builders, and private and governmental funds.

Foreign investment in Morocco. Morocco is continuously striving to attract international investors by improving all aspects related to the industries and trading. According to the global competitiveness World Economic Forum Index 2016-2017, the country is second in Africa in terms of infrastructure. In less than a decade, the country has leveled up its infrastructure to international standards. The Kingdom of Morocco has the 
12th most competitive rate of the cost of export worldwide and has a low tax rate of $49.3 \%$ of profits. Morocco established a legal framework to improve its trade ties with more than 55 countries. $^{71}$

Space in Morocco. Morocco was one of the first nations to join the United Nation Office for Outer Space Affairs (UNOOSA) committee on the peaceful use of the outer space, they joined in $1961{ }^{72}$ The country has ratified five United Nations treaties on outer space: The Outer Space Treaty, the Rescue Agreement, the Liability Convention, the Registration Convention, and the Moon Agreement. The kingdom is currently developing a national space law. ${ }^{73}$ Morocco is home for the UN African Regional Centre for Space Science and technology education-French language. Moroccan space program is 30 years old and has two major space institutions, which are under the Ministry of Defence: the first is The Royal Centre for Space Research and Studies: CRERS, created in 2001 and was created to develop the Moroccan space technology and launched the first experimental satellite of Morocco in the same year in collaboration with Berlin Technical University.

Also, the second, The Royal Centre for Remote Sensing: CRTS: responsible for the use of the remote sensing applications, carries it out in collaboration with ministries, universities, and the private sector. This center is responsible for the promotion of the Earth observation in Morocco, promotion of space law and technologies to raise awareness among decision-makers and the public. It is currently operating the two earth observation satellites of Morocco. ${ }^{74}$

The country space policy aims to:

- Contribute to the treatment of the national/regional and international issues.

- Promote space law.

- Develop new services in the field.

- Promote south/south cooperation.

- Empowering Moroccans on earth observation scientific technology and applications and enhancing their skills.

- Raising community awareness of and culture in space technology and its applications. ${ }^{73}$

International cooperation. The center has many international partners: European Space Agency, National Aeronautics and Space Administration, Centre National d'Études Spatiales, and United Arabs Emirates Space Agency are part of many international organizations such as the International Astronautical Federation, United Nations Development Program, and Committee on Peaceful Use of Outer Space. On the African level, Morocco is a part of many cooperation initiatives: Tiger,
Global Monitoring for Environment and Security (GMESAfrica), SERVIR-AFRICA, which are mainly concerned with remote sensing. ${ }^{74}$

\section{Ghana}

Ghana is on the quest to serve as the hub of space science and technology in Africa, it was among the countries in a bid to host the headquarters of the African Space Agency of the African Union. ${ }^{75}$ This gesture shows the government's political will power to support and invest in the space science sector. A demonstration of this effect was the announcement of the 12 million USD contract by the government in 2018 to assist the health sector in transporting medical essentials and blood to deprived communities with the use of drones and satellite navigation technology. ${ }^{76}$ Ghana is rated second to South Africa on results of politician and bureaucrat indicators followed by Algeria, Egypt, and Nigeria, respectively, from table 8 by Sumah. ${ }^{77}$

Privatization and commercialization of space science technology are indeed the way to go in Africa. Ghana in June 2017 launched its first satellite (GhanaSat-1) into space, and this was achieved by a private entity (All Nations University College) initiative in collaboration with other interested parties. ${ }^{78}$ Ghana is positioned 5 degrees north of the equator and has the advantage to view the entire Milky Way galaxy and nearly the whole sky. It is not surprising that the country hosts Africa's largest single radio telescope (32 m dish-Ghana Radio Astronomy Observatory) for innovation, commercialization, and world-class research as part of the Square Kilometre Array (SKA) Project in building the world's largest telescope. ${ }^{79}$ These interventions by the government and private entities drive the growing interest in the commercial space industry and research.

According to the regional policy on science and technology adopted by the Economic Community of West African States in 2011, Ghana is keen among countries with industries producing value-added products. This policy highlights Ghana and Nigeria hosting specialized institutes for aeronautics, chemistry, metallurgy, and others creating an enabling environment for emerging business and enterprise. The main objectives of the original National Science, Technology and Innovation Policy (2010) by the UNESCO Science Report were to utilize science technology and innovation (STI) for poverty reduction, heighten the international competitiveness of enterprises, and promote sustainable environmental management and industrial growth. ${ }^{80}$ Ghana in July 2019 beat six other countries that had submitted their bids to host the secretariat of the African Continental Free Trade Area (AfCFTA) ${ }^{81}$ This is an initiative aimed to implement the free trade 
deal creating a common market for the over 1.2 billion people in Africa and arguably the largest free trade area in the world. A report by Bloomberg projected Ghana to be the fastest growing economy in the world in 2019, according to the International Monetary Fund. It reported that six of the world's fastest growing economies are in Africa with Ghana leading the forecast. ${ }^{82}$ Ghana, therefore, fits positively based on " GEF" critical dimensions of environments for entrepreneurship development in the space sector.

In terms of positioning Ghana using the dual double diamond model developed by Cho et al., Ghana is ranked third in table 10 by Sumah on the overall indicators on the competitiveness ranking of African space nations for South Africa, Egypt, Ghana, Algeria and Nigeria, respectively, by comparing both the domestic and international indicators. ${ }^{77,83}$

The national space agency, Ghana Space Science and Technology Institute (GSSTI), works coherently with other private and public agencies in achieving its mandate. ${ }^{84} \mathrm{Al}-$ though there are challenges in funding, human resources, policies, educational sectors, and others, the stable political and socioeconomic environment of Ghana makes it ideal for the space science market.

\section{Sudan}

Entrepreneurial environment in Sudan. According to the Global Entrepreneurship Monitor (GEM) report 2018-2019, ${ }^{85} \mathrm{Su}$ dan's entrepreneurial potential is generally socially supported but with limited government support in terms of policies and financial support. Among the 47 nations covered by the societal value of entrepreneurship questionnaire of the report, Sudan ranks as number 1 in giving high status for entrepreneurs, and as number 7 in stating entrepreneurial track as a right career choice. Moreover, the internal market dynamics in Sudan is the highest among all the 54 countries participating in the survey. The space sector is not an exemption of these bounding entrepreneurial conditions. The next subsection is on the space sector's current status to assess the potential for the space sector to flourish if the overall entrepreneurial conditions in the country improve.

Space agency and research centers in Sudan. According to the UNOOSA report on the activities of member states in $2018,^{86}$ space activities in Sudan have been going on since the early 1970s at some governmental departments. The Remote Sensing Centre was then established in 1977 under the umbrella of the National Centre for Research. In 2012, the Institute of Space Research and Aerospace (ISRA) was also established under the same big umbrella to undertake specific research and development activities in space science and aerospace engineering. Other government centers were also established and reported in the same source, including the Ceres Space Technology Centre. Moreover, universities in Sudan have reported activities in both developing space technologies and in utilizing space data (remote sensing, telecommunication, navigation, and astronomy), including the University of Khartoum and Future University. ${ }^{87}$ At the University of Khartoum, the first cube satellite project in Sudan was established in 2010. A space research center was then established too at the same university. However, the space activities at the universities have been going on way earlier before 2010 .

A report presented at the UNOOSA by the University of Khartoum Space Research Centre shows that space research has been present in thesis and dissertations since the $1970 \mathrm{~s}$ and it has been utilized to cover 14 out of the 17 sustainable development goals by research held at the University of Khartoum alone ${ }^{88}$ A notable publication from the Africa Initiative for Planetary and Space Sciences surveyed the number of publications in space science and technology in Africa and the correlation of this number with the availability of space infrastructures (satellites in orbit, observatories, and possibility as launch sites), which are shown in a complementary map in Figure $3 .^{89}$ It also reported Sudan activities in space research, however, it is the only country in the regular publishing countries that do not own any of the infrastructures mentioned above, as of 2019. This is an indicator of the availability of knowledge in these domains in Sudan regardless of the absence of infrastructure.

Commercial space activities in Sudan. In the same UNOOSA report on the activities of member states in 2018, it was reported that government-supported companies had been established already. ${ }^{86}$ Mierag Space Technologies Company was established in 2002 by the Ministry of Science and Technology to support both governmental and private sectors with GIS data. ${ }^{90}$ On the contrary, Sudasat Company, which is a joint venture between Sudatel Telecom Group Limited and Haggar Holding Company Ltd., provides VSAT services in Sudan, the Middle East, and Africa. ${ }^{91}$ The company also operates its ground station facilities and provides satellite ground station services for Arabsat. ${ }^{92}$

In conclusion, knowing that many universities are active in utilizing space data, we can confidently state that the research and development backbone needed to support entrepreneurial space activities is available when needed, especially in the utilization of space data and services. Moreover, the existence of the mentioned companies in the market already provides the market experts needed to support space start-ups in the future. 


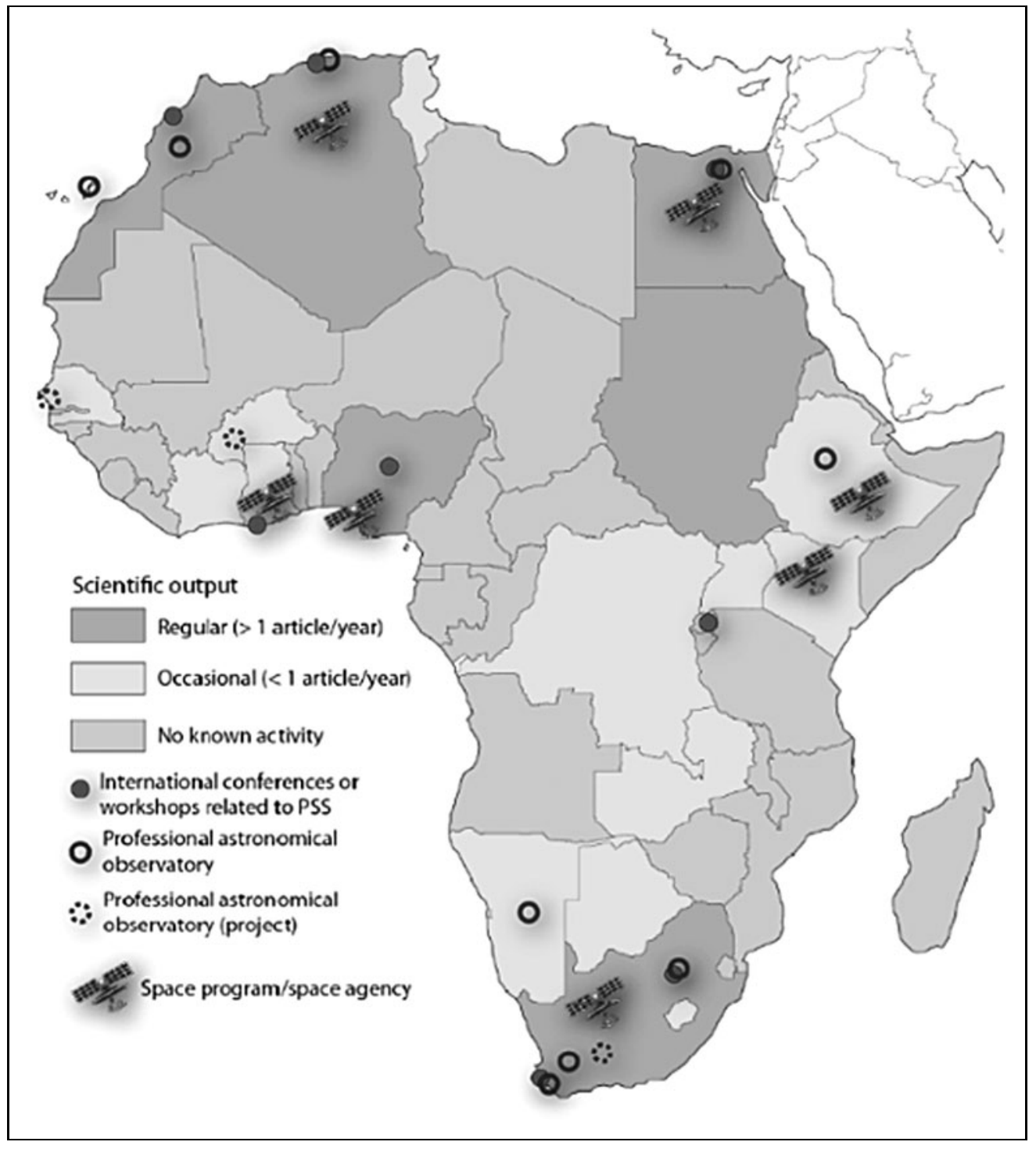

Fig. 3. Map illustrating the emerging activities in planetary and space sciences in Africa. PSS, Planetary and Space Sciences.

\section{Tunisia}

The interest in the peaceful exploration of space started since the launch of the first satellite in space in 1957 that had as consequences the creation of the National Commission of outer space in 1984 and the National Centre of cartography and remote sensing in 1988, named as the National Centre for Cartography and Remote Sensing in 2009. Considering the benefits of space in the socioeconomic development, Tunisia started thinking about adequate environment and conditions to establish a space base. ${ }^{90}$

In 2010, the National Commission for Extra-Atmospheric Space started working on the participation of Tunisia in the work of the United Nations Committee on the Peaceful Uses of Outer Space (COPUOS) and its membership as a member country since December 2010, which has contributed to the creation of the five subcommittees following the UNOOSA framework: the Subcommittee "Earth Observation," Space Technologies Subcommittee, the Subcommittee "Space Communication," the Subcommittee "Legal and Legal Affairs," and the Subcommittee, "Training and Research in Space Technologies." Each one of these subcommittee aims to enhance the application of the UNOOSA for the peaceful uses of the outer space in the service of the country. ${ }^{91}$

This has been a considerable step toward space development in Tunisia. However, challenges have limited the work of these units and the application of the agreed objectives. Among these challenges, we mention that there were no centralization and official agency to manage the work of the country in the space field. The little interest in space has been a big issue as well; having no response does not allow the development of space applications in Tunisia, which explains the absence of specific projects for the basic needs of the country (earth observation, telecommunication, and agriculture). We should not forget that the lack of coordination between the different actors limits the use of the space application for the service of the socioeconomic goals. All these issues and challenges have caught the attention of different stakeholders in Tunisia. Meetings took place, and a symposium resulted in the Tunisian national strategy for space technologies in March 2018.

The goal of this symposium was the reunion of the different actors to solve the problems above having other international experts. ${ }^{92}$ This event has been crucial in the definition of the different uses of space applications, needs, and priorities in Tunisia, analysis of the strengths, weaknesses, opportunities, and threats (SWOT analysis). As a consequence, to this work, it is evident that the establishment of an environment that 
enables the use and exploitation of space technologies operationally to meet the needs expressed at the national level for the country's development, collaborating with other countries in the region as well as on an international level for global goals, is crucial. Indeed, to make this field operational and for the application of a space strategy, this should first include the organization of this sector by a national partnership and by raising the awareness of space application for the interest of the country by developing space training programs, including space education in universities and schools, developing the space research, and mostly defining the needed infrastructure (research centers, ground stations, control centers, among others.)

\section{QUESTIONNAIRE ANALYSIS}

We got 30 responses from 13 different countries, with $76.76 \%$ from Africa and 23.33\% from non-African countries that also partook in the analysis, including India (which is one of the emerging countries, GLEC), Iran, Ukraine, the United States, and the Netherlands. They form a very small percentage of the data gathered, but from their responses gave means to a clearer perspective on target assessment of the African space sector, in lieu of future collaboration within an ASA. Out of the respondents, about half (14 out of 30) had no affiliation with any national space agency of their respective countries. We had targeted questionnaire inquiries to those with the knowledge of the African space sector. Moreover, to weigh in some balance, we also took inputs from personnel of pure technical backgrounds, which are the 16 out of 30, who are respected in their chosen field of research and with affiliation to space agencies.

The first set of questions was to evaluate the awareness of our respondents on the existence of the HOM study, and if they knew of the frameworks we had planned to use for our analysis (Fig. 4). Only 20\% of them had prior knowledge of G\&F "key dimensions of environments for entrepreneurship development," and Michael Porter's Competitive Advantage Theory. ${ }^{6,8}$ However, almost half (46.7\%) knew of the HOM study. We also verified roots to affirm the existence of an ASA. Thirty percent responded with "NO," 40\% affirmed the existence, while 30\% of the respondents sat on the fence (a "maybe"). However, the first feasibility study for an ASA was commissioned by the African Union back in 2011. ${ }^{10}$ ASA policies and strategies also came into being in 2015, and an expectation that the first official ASA Conference will be held during the year 2019.

More than $80 \%$ of the responding community believes Africa is a potential market for the next-generation private space. The subcontinent is a primary focus for more than $20 \%$ of the international community who wishes to exploit this potential market for the healthy growth of the private space sector. On the market target assessment shown in Figure 5, from the analyzed opinions of a total of 30 respondents, $40 \%$ asserted of Africa advancing space community with a formal governing agency. The global space community is aware of the space enthusiasts and researchers blooming in the African subcontinent. The questionnaire focused on seeking people's suggestions on their views of Africa's potential space market. They strongly believe that Africa has an unexplored market in telecommunication (18\%), agriculture and forestry (14\%), weather forecasting and data management (11\%), and several other sectors depicted in the graph. Educational purpose and remote sensing are the next big markets for the African space sector. The analysis is contributed by more than $25 \%$ of the non-African community, which reflects a potential future of the subcontinent's space growth. Test bed simulation for Mars and the lunar surface are still a dubious sector to be exploited on, but the scientific community affirms its research stems to African geographical and climatic conditions for humans training in simulation environments.

\section{DISCUSSION}

BRICS countries began the alliance informally around 2006 when the four foreign ministers of Brazil, the Russian Federation, India, and China coordinated an informal meeting on the sidelines of the United Nations General Assembly. ${ }^{93}$ The first BRICS summit took place in 2009 in Yekaterinburg, Russia, where the Heads of State and Government gathered to discuss the activities in several areas of cooperation. ${ }^{94}$ In 2011, South Africa became a member by attending the Sanya Summit in China. ${ }^{95}$ The summits are held yearly in the respective countries. The group has two main pillars: (1) coordination in multilateral fora, with a focus on economic and political governance; and (2) cooperation between members. ${ }^{96}$ BRICS has a joint bank "New Development Bank" that was formed in 2014, headquartered in Shanghai, China, with its first regional office in Johannesburg, South Africa. ${ }^{97}$

Currently, the countries have over 30 sectors of cooperation and are planning debate on the possibility of more, including the space industry. The BRICS countries have relatively powerful space agencies: India with ISR0, China with CNSA, Russia with ROSCOSMOS, South Africa with SANSA, and Brazil with AEB. Those space agencies are mostly working in a bilateral regime, taking the example of Russia that is planning to train the Indian astronauts, ${ }^{98}$ or inter-BRICS with the remote sensing constellation that the parties are planning to launch. ${ }^{99}$ All these nations have rocket launch sites, used for military, testing, satellite launching, or scientific purposes. The African Union has 55 member states located on the 
a Are you aware of Human Orbital Market Research?

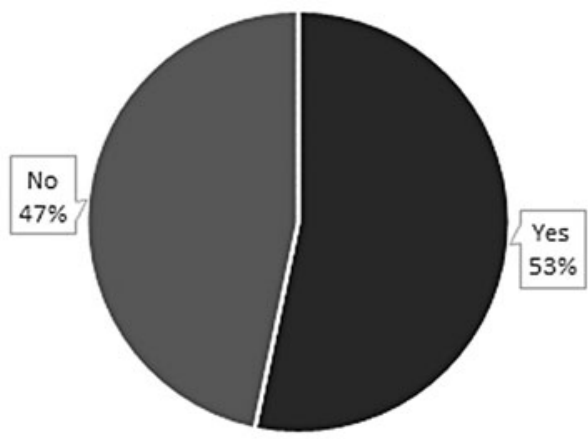

C

Is there an African Space Agency?

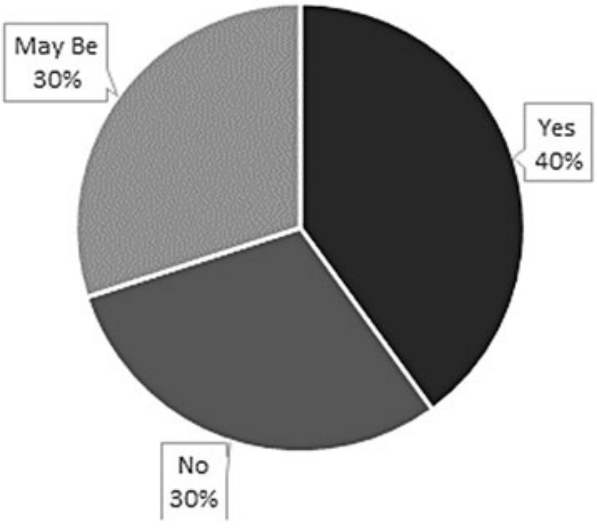

b Do you think there is entrepreneurial potential for the African Space Sector?

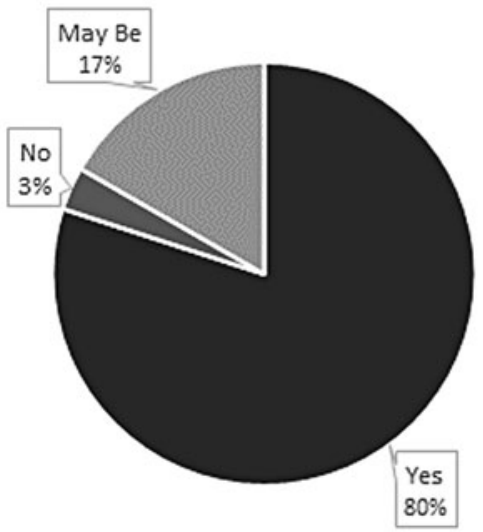

d

Are you aware of entrepreneurial tools: Gynawali \& Fogel' key dimensions and advantage of Diamond Model of Michael Porter?

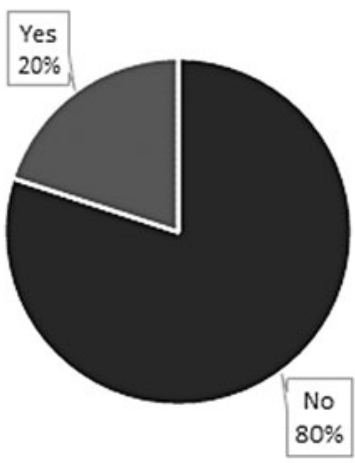

Fig. 4. Showing the awareness of the respondents on the tools and framework used in the analyses. Pie-charted responses on questions such as: (a) Are you aware of Human Orbital Market (HOM) research? (b) Do you think there is entrepreneurial potential for the African Space Sector? (c) Is there an African Space Agency? (d) Are you aware of the entrepreneurial tools: Gynawali \& Fogel's key dimensions and advantage of diamond model of Micheal Porter?

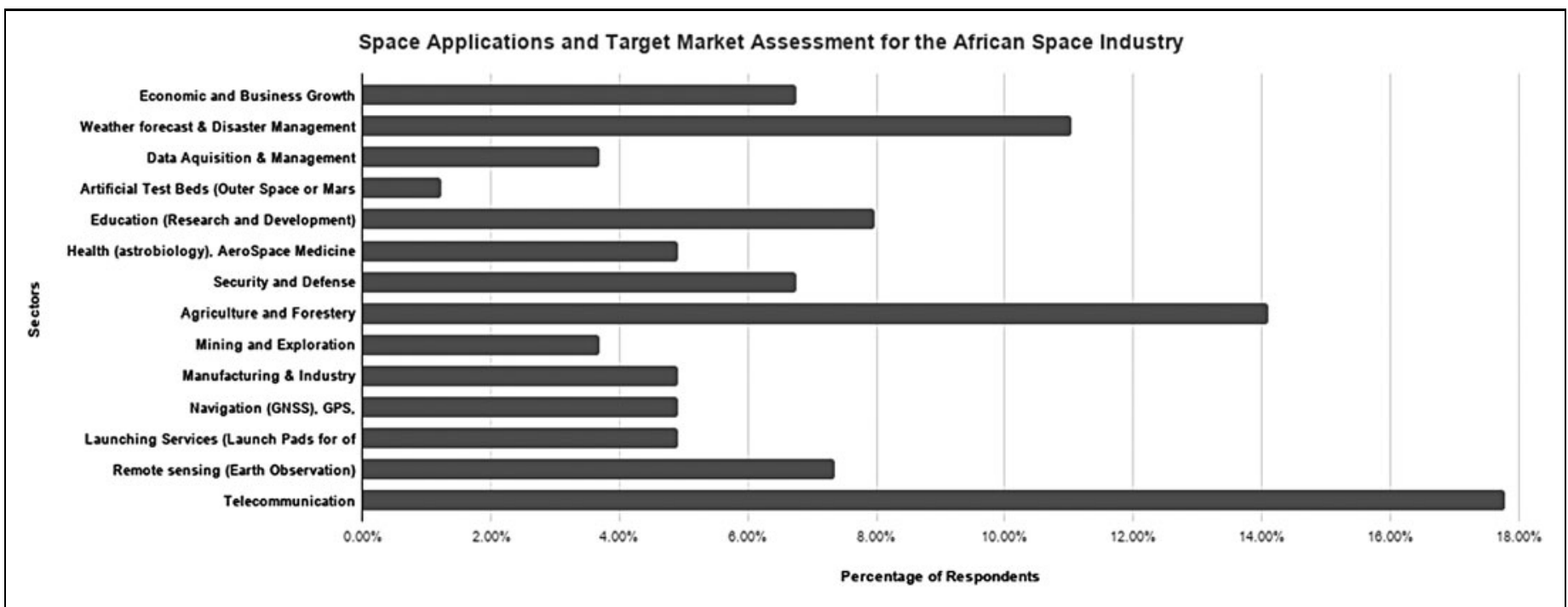

Fig. 5. The target assessment of the areas the respondents noted as domains for vibrant space applications, applicable to African countries with active space industries and areas of policy strategy for the ASA. ASA, African Space Agency. 
continent of Africa. Started in 2002, ${ }^{100}$ the union's administrative headquarter is in Addis Ababa, Ethiopia. Their work is implemented through several organizations and committees for decision-making, judicial and legal matters, and human rights. The nations are working on the establishment of a continental financing institution. ${ }^{101}$

The African Union, just like BRICS, has a development bank group: African Development Bank Group with the African Development Bank (AfDB) and the African Development Fund. ${ }^{102}$ The group has African and non-African members. Brazil, India, and China are nations that form the nonregional members of the $\mathrm{AfDB}^{102}$ The African Union has created the Science, Technology and Innovation Strategy for Africa (STISA-2024), a 10-year strategy to respond to the demands of science, technology, and innovation in prioritized sectors: agriculture, health, infrastructure, development, and wealth. The main goal of the strategy is to catalyze growth toward an innovative economy, encouraging each country to take at least 1\% of its GDP to invest in research and development: having a domestic would improve implementation and reduce over-reliance on external resources. The African space sector has seen massive growth over the years. According to the Africa industry report for 2019, the African space industry is in a drastic growth from 1998 through 2019, with over 35 satellites being launched by different African countries (Fig. 6), it is now worth US \$7 billion. ${ }^{103}$ Projections show that the continent is likely to grow by $40 \%$ in the next 5 years. The first African satellite was launched in 1998 (Egypt). The African space is still in its dawn even though many of its members have national space programs. Some countries have regional space centers, taking the example of the Regional Centre for Remote Sensing North African States (CRTEAN), which comprises Algeria, Mauritania, Morocco, Tunisia, Libya, Egypt, and Sudan ${ }^{104}$ with their headquarters domicile in Tunisia. They have been permanent observers of the Committee on the Peaceful Uses of Outer Space (COPUOS) since 2003. ${ }^{105}$

The union is currently working on the establishment of a continental space agency of which the legislative for establishment was passed in
2017. ${ }^{106}$ The African nations have launched over 29 satellites. To access the readiness of the selected African countries, we evaluated the number of international agreements (treaties) acknowledged, signed, or ratified. Table 3 shows the findings in this regard. The data for both Sudan and Morocco are not presented in the table. Sudan (joined 1973) has a no agreement status, while Morocco, which joined 1961, has ratified all the five treaties for Peaceful Uses of Outer Space. ${ }^{106}$

\section{Evaluating World Bank Data on African Countries}

Table 4 presents the data of the considered countries. The ease of doing business in the selected countries varies due to the difference in the laws, the policies, and the procedures followed. Mauritius is exceeding all the countries from BRICS and is ranked first on the African level, while Sudan is last in the chosen countries list. For the BRICS part, the Russian Federation is first while Brazil is last. The net inflow and FDI show the difference between the African countries and the BRICS countries as we go from the astronomical sums earned by the BRICS countries; in 2017, China with almost $\$ 170 \mathrm{~B}$ and

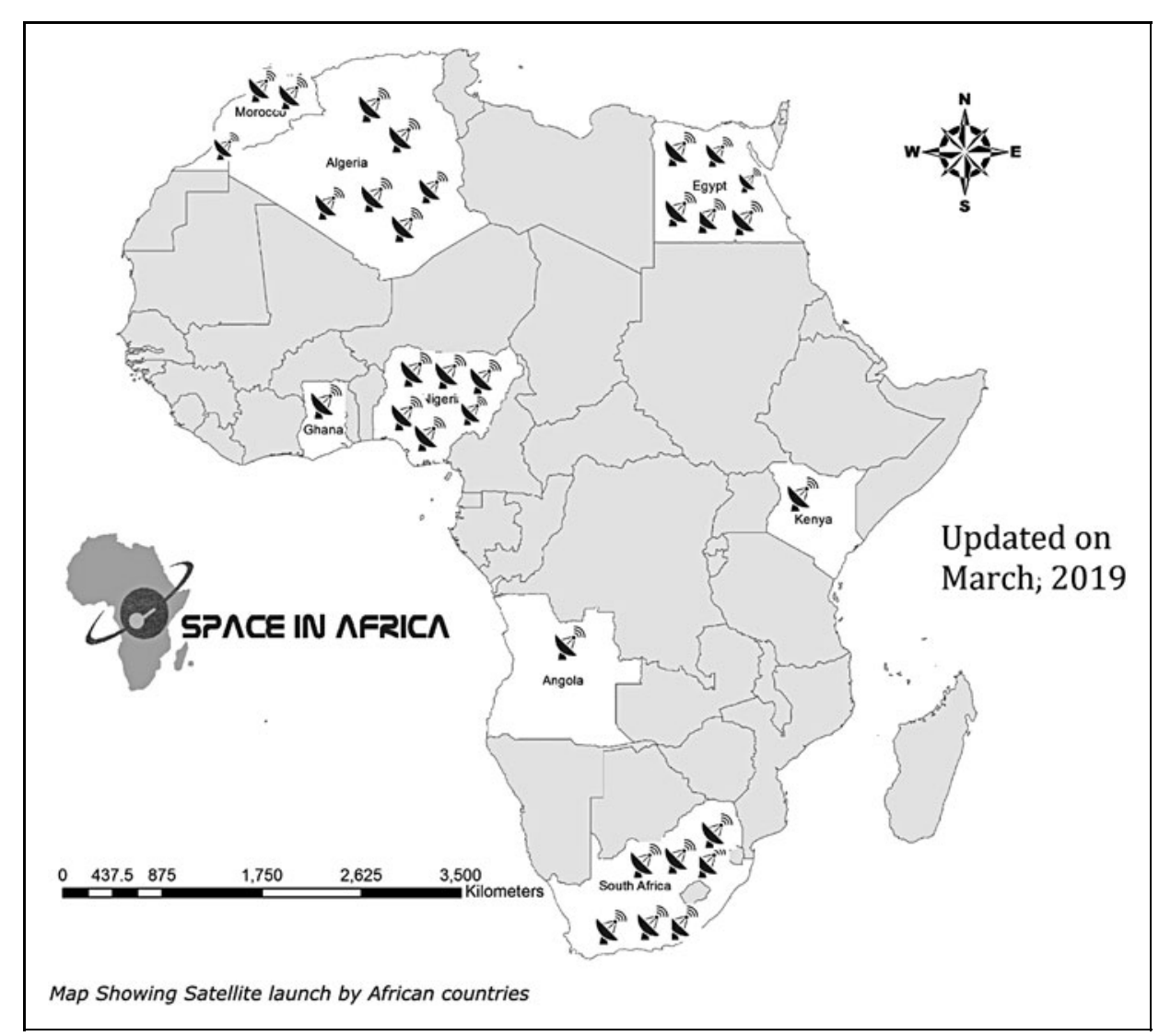

Fig. 6. Map showing satellites of the respective African countries. 
Table 3. United Nations - "COPUOS" ("Committee on the Peaceful Uses of Outer Space") Treaties and Ratification Status of the Countries ${ }^{102,103}$

\begin{tabular}{l|c|c|c|c|c|c} 
UN Space Treaties & India & SA & NIG & GH & TUN & MAU \\
\hline Year & 1958 & 1994 & 1973 & 2013 & 2010 & 2018 \\
\hline Outer Space Treaty & $\mathrm{R}$ & $\mathrm{R}$ & $\mathrm{R}$ & $\mathrm{S}$ & $\mathrm{R}$ & $\mathrm{R}$ \\
\hline Rescue Agreement & $\mathrm{R}$ & $\mathrm{R}$ & $\mathrm{R}$ & $\mathrm{S}$ & $\mathrm{R}$ & $\mathrm{R}$ \\
\hline Liability Agreement & $\mathrm{R}$ & $\mathrm{R}$ & $\mathrm{R}$ & $\mathrm{S}$ & $\mathrm{R}$ & $\mathrm{N} / \mathrm{A}$ \\
\hline Registration Convention & $\mathrm{R}$ & $\mathrm{R}$ & $\mathrm{R}$ & $\mathrm{N} / \mathrm{A}$ & $\mathrm{N} / \mathrm{A}$ & $\mathrm{N} / \mathrm{A}$ \\
\hline Moon Agreement & N/A & N/A & N/A & N/A & N/A & N/A \\
\hline
\end{tabular}

BRA, Brazil; GH, Ghana; MAU, Mauritius; R, ratified; MOR, Morocco; N/A, no agreement yet; NIG, Nigeria; RUS, Russia; S, signed; SA, South Africa; SU, Sudan; TUN, Tunisia.

a minimum of $\$ 2.1 \mathrm{~B}$ for South Africa. For African countries, a maximum of $\$ 3.5 \mathrm{~B}$ for Nigeria and a minimum of $\$ 0.44 \mathrm{~B}$ for Mauritius.

The GDP scores as for 2018 show the contrast between the BRICS countries and the African countries. China is ranked first worldwide with a $\$ 13.6 \mathrm{~T}$, followed by India, which is second on the BRICS level and third worldwide with \$2.72T

Table 4. Showing the Ranking of All Countries Studied According to the Ease of Doing Business

\begin{tabular}{l|l|c|c|c}
$\begin{array}{l}\text { Ranking } \\
(\mathbf{2 0 1 8 )}\end{array}$ & \multicolumn{1}{|c|}{ Country } & $\begin{array}{c}\text { Ease of Doing } \\
\text { Business Index }\end{array}$ & $\begin{array}{c}\text { Population } \\
\left(\times 1 \mathbf{0}^{\mathbf{3}}\right)\end{array}$ & GDP \\
\hline 1 & Mauritius & 20 & 1,265 & $\$ 30 \mathrm{~B}$ \\
\hline 2 & Russian & 31 & 144,478 & $\$ 4 \mathrm{~T}$ \\
\hline 3 & China & 46 & $1,392,730$ & $\$ 25 \mathrm{~T}$ \\
\hline 4 & Morocco & 60 & 36,029 & $\$ 314 \mathrm{~B}$ \\
\hline 5 & India & 77 & $1,352,617$ & $\$ 10.5 \mathrm{~T}$ \\
\hline 6 & Tunisia & 80 & 11,565 & $\$ 144 \mathrm{~B}$ \\
\hline 7 & South Africa & 82 & 57,780 & $\$ 793 \mathrm{~B}$ \\
\hline 8 & Brazil & 109 & 209,469 & $\$ 3.4 \mathrm{~T}$ \\
\hline 9 & Ghana & 114 & 29,767 & $\$ 141 \mathrm{~B}$ \\
\hline 10 & Nigeria & 146 & 195,875 & $\$ 1.2 \mathrm{~T}$ \\
\hline 11 & Sudan & 162 & 41,802 & $\$ 198 \mathrm{~B}$ \\
\hline
\end{tabular}

Data adapted from Worldbank.org. GDP, gross domestic product. and a minimum of \$0.73T for South Africa. For the African level, Nigeria is first and only 24th worldwide with a GDP of $\$ 1.17 \mathrm{~T}$ and a minimum of $\$ 29.99 \mathrm{~B}$ for Mauritius. For the population, China and India lead the rankings worldwide as they are first $(1,392,730.00)$ and second $(1,352,617.33)$, respectively, giving both countries more workforce and higher FDI. For the African case, Nigeria is leading the ranking with a population of 195,874.74 while being seventh on the international level. Mauritius has the least population with 1,265,303. Figure 7 also shows the FDI net inflow as the percentage of GDP on the vertical axis between 2007 and 2017. It can be seen that Ghana has a relatively higher percentage of its GDP as a result of FDI in the country, however, countries such as Nigeria and South Africa with larger economies have a considerably lower percentage of the GDP as FDI net inflow.

For the science and technology data, China is leading the ranking for the scientific and technical journal publications and for the research and development expenditure, which is due to the high number of population and interest in innovation of the country. India follows for scientific and technical journal publication, followed by Brazil in the research and development expenditure. South Africa is last in the BRICS ranking in both categories while being first in the African case. Morocco is following South Africa in the research and development expenditure, while Nigeria is following for publication. Mauritius comes last in research and development expenditure and in scientific and technical journal publication ranking.

It can be perceived that the growth trend in research still has the uptrend in most of the studied African countries, shown in Figure 8. One wide distinction is the axis on the right showing that a different scale was required to provide visualization of research out of India and the selected African countries. A clear conclusion that can be drawn is that African countries will need to prioritize research and development more, if there is still an interest to be part of the growing space market. Based on the understanding of the Porter's stages of competitive advantage, ASA should make REtD a sole priority to allow for transition from inherent investment stage to the innovative stage.

\section{CONCLUSIONS}

G\&F key dimensions of environments for entrepreneurship development were adopted for this research analysis to understand the entrepreneurial environment of some of the selected countries: Nigeria, Ghana, Morocco, Sudan, and Tunisia. The key activities of development for these countries are more awareness and engagement in space science and technology. The NGMMS are gradually growing in GDP, which is giving room for greater economy in these countries. Moreover, with 


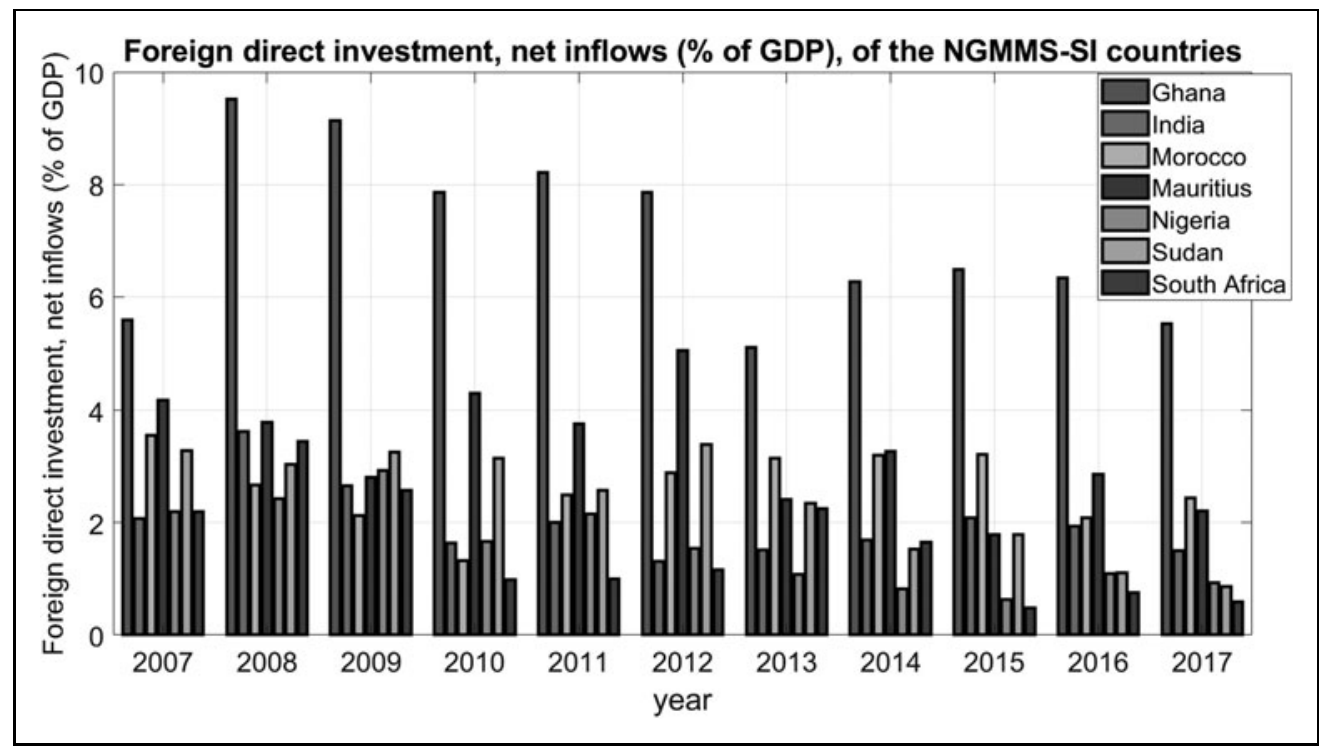

Fig. 7. Foreign direct investment, net inflows (\% of GDP), of the studied countries - Nigeria, Ghana, Morocco, Mauritius, Sudan, South Africa, India.

population increase bound to continue, more youths are expected to develop solutions to various challenges with a smart technology solution. The analysis gave a good result outlook that investors can directly or indirectly penetrate the growing African space industry by financing start-ups to develop solutions and service the African economy.

With significant progress still relying on government activities within the region, and policies, politics, and the willingness to provide a conducive environment to encouraging innovation

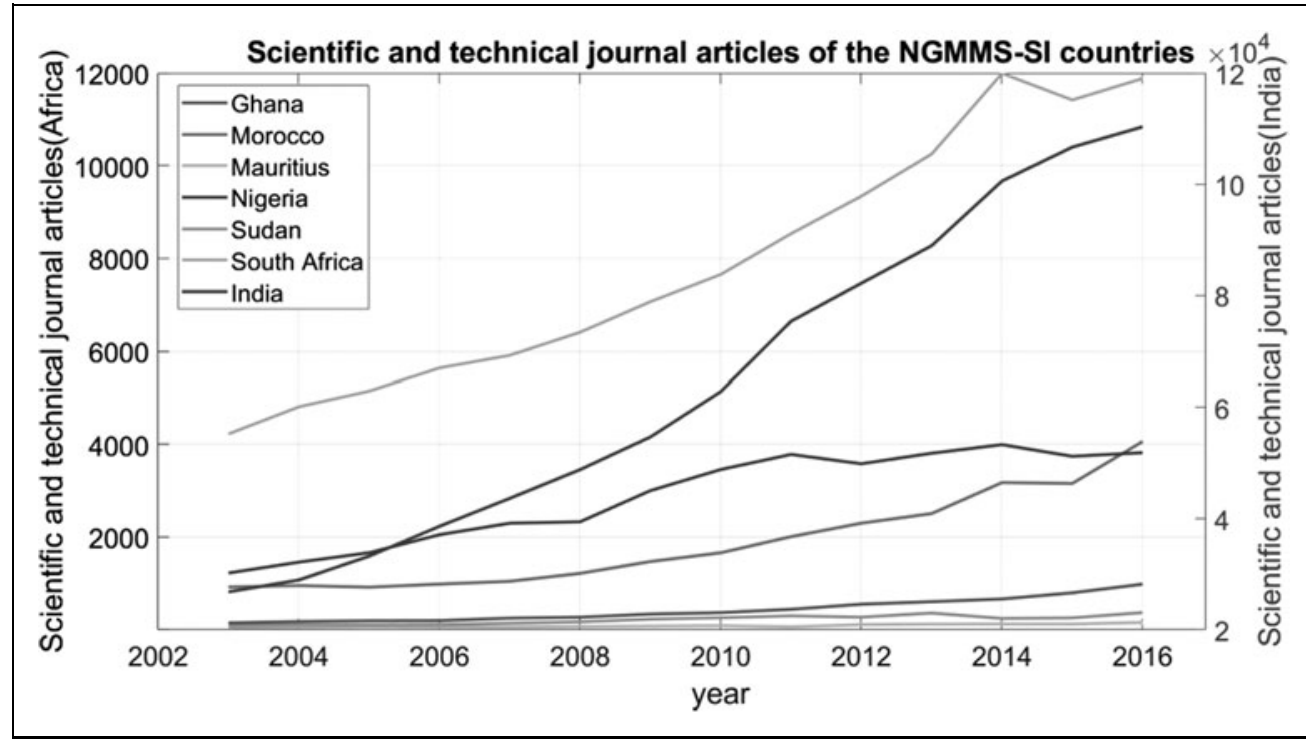

Fig. 8. Comparing yearly volume publications for India and the NGMMS-S countries. NGMMS-SI, Nigeria, Ghana, Morocco, Mauritius, Sudan, - South Africa, India. and cross-industry space competitiveness, it is crucial that the governments of the countries consider to start reviewing their policies and give room for more investors to operate in the region. To allow a thriving African space sector, the views of the respondents on paths to take are on reforming policies, strengthening the education sectors and the impoverished entrepreneurial access to adequate support, and backing to allow for ease of making business in Africa to allow the applications suggested from this analysis to take place efficiently.

\section{Limitations and Future Research}

In this particular research analysis, the five countries considered were as a result of the experts interested and available; other significant spaces active (or emerging actors) could have been considered, a limitation was national representative experts being unavailable for the time frame of the completion of this article, significant examples are South Africa and Mauritius, which were in the earlier plan for analysis, but it was firmly challenging to access the NPoCs for these countries.

This analysis does not entirely give a very detailed analysis of each country; subsequent articles for individual countries can dive more deeply into the entrepreneurial strength of each nationalism. The perspective of policy influence on some parts of the analysis was also not considered, although a part of the significant economic backbone. Detailed analysis is needed for other space-faring countries that were not mentioned in this article. Future work entails expanding the HOM framework for the entrepreneurial analysis of these countries. This will give support to the ASA policy implementation strategy. 


\section{ACKNOWLEDGMENTS}

Posthumous acknoweledge to Prof Toloye A.A. Asiyanbola (1960-2020), who assited with editorial guidance for jounal publications.

We thank the coordinators of the commercial space project group (CSPG) under SGAC for initiating this project for Africa. We also thank Ken Davidian, Charlotte Kiang (Business Lead for CSPG), and Funmi Erinfolami of the ARCSSTE-E, Nigeria, for their support and guidance on this work.

The section on Tunisia was based on the previous documents, data from members of the CNCT, and Rania Toukebri's analysis after participation in national and international events UNCOPUOS 61st session, UNCOPUOS 56th STSC, UN Symposium, and Tunisian Symposium 2017.

\section{DISCLAIMER}

The conclusions of this report remain those of the study's authors and no statement found herein should be attributed to any individual or organization. Participation in this study does not also constitute an endorsement of this study nor its conclusion.

\section{AUTHOR DISCLOSURE STATEMENT}

No competing financial interests exist.

\section{FUNDING INFORMATION}

No funding was recieved for this project, SGAC is a nonprofit organization.

\section{REFERENCES}

1. Mankiw NG. Principles of Economics. Cengage Learning, 2014. CT, USA. www.cengage.com/global.

2. Sachs JD, and Warner AM. Economic Convergence and Economic Policies. No. w5039. National Bureau of Economic Research working paper, 1995. https://papers.ssrn.com/sol3/papers.cfm?abstract_id=225818.

3. Moghalu K. Africa as the Last Frontier: Why It Matters in the Global Economy | Wilson Centre. 2013. https://www.wilsoncenter.org/event/africa-the-lastfrontier-why-it-matters-the-global-economy (Last accessed October 5, 2019).

4. The Non-Aligned Movement: Background Information. https://web.archive .org/web/20160209210107/http://www.nam.gov.za/background/background .htm (Last accessed October 5, 2019).

5. Ake C. A Political Economy of AFRICA. Vol. 4. London: Longman, 1981.

6. Gnyawali DR, Fogel DS. Environments for entrepreneurship development: key dimensions and research implications. Entrep Theory Pract. 1994;18(4): 43-62.

7. Kiang C. Evaluating the Potential for Commercial Space Industry Growth: An Entrepreneurial Environment Analysis of Japan. 66th International Astronautical Congress, Jerusalem, Israel, 2015.

8. Porter ME. Porter on Competition and Strategy. Harvard Business Review Press, Boston, Massachusetts, United States, 1991.

9. Sharpe C. Space Economic Readiness-Economic Analysis for Public Funding of Space Technology in Developing African Countries. MBA Dissertation, International Space University, ISU, Strasbourg, France, 2010.
10. Feasibility Study-Creation of an African Space Agency. Commission of the African Union by VEGA Technologies SAS Villa San Diego, Parc Technologique du Canal, France, 2011.

11. Di Pippo S, Davidian K. Public/Private Human Access to Space. 64th International Astronautical Congress, Chinese Society of Astronautics (CSA), Beijing, China. 2013. https://www.iafastro.org/events/iac/iac-2013/.

12. Autry G, Huang L. An analysis of the competitive advantage of the United States of America in commercial human orbital spaceflight markets. New Space. 2014;2(2):83-110.

13. Autry G, Davidian KJ. A Review of the Competitive Advantage of the United States of America in Commercial Human Orbital Spaceflight Markets. In AIAA SPACE 2014 Conference and Exposition, p. 4202, 2014.

14. Bodner M. Russia to Propose BRICS Space Station. 2015. https://www.themo scowtimes.com/2015/01/27/russia-to-propose-brics-space-station-a43279 (Last accessed October 6, 2019).

15. Russia Ready to Help India with 2022 Space Mission. http://infobrics.org/post/ 27807/ (Last accessed October 6, 2019).

16. List of the African Countries by Population. 2018. http://statisticstimes.com/ demographics/african-countries-by-population.php (Last accessed July 11, 2019).

17. African Countries by Population. 2019. https://www.worldometers.info/ population/countries-in-africa-by-population (Last accessed July 10, 2019).

18. The Population of African Countries in Africa 2019. http://worldpopulation review.com/countries/countries-in-africa (Last accessed July 12, 2019).

19. Africa, Nigeria and their growing tech community. https://github.blog/2018-0221-africa-nigeria-and-their-growing-tech-communities (Last accessed July 10, 2019).

20. Nigeria Economic Outlook. https://www.afdb.org/en/countries/west-africa/ nigeria/nigeria-economic-outlook (Last accessed July 12, 2019).

21. The economic context of Nigeria. https://www.nordeatrade.com/en/explorenew-market/nigeria/economical-context (Last accessed July 12, 2019).

22. West and Central African Higher Education Centres of Excellence Project. https://ace.aau.org (Last accessed July 12, 2019).

23. Adekunle. World Bank Rates African Centres of Excellence in Nigeria High. 2016. https://www.vanguardngr.com/2016/06/652888 (Last accessed July 12, 2019).

24. OAU ICT Driven Knowledge Park (OAK Park). https://www.ace.edu.ng/ace/ centres/oak_park/ (Last accessed July 12, 2019).

25. Space Generation Advisory Council. https://spacegeneration.org/ (Last accessed July 12, 2019).

26. African Regional Centre for Space Science and Technology Education in English. http://arcsstee.org.ng/home/ (Last accessed July 12, 2019).

27. African Regional Centre for Space Science and Technology Education-in English Language (ARCSSTE-E). United Nations Office for Outer Space Affairs. http://www.unoosa.org/oosa/en/ourwork/psa/regional-centres/arcsste-e.html (Last accessed July 12, 2019).

28. Vaayough HM. Novel Approaches by Nigeria's Space Agency (NASRDA) in Geospatial Intelligence Training and Capacity Development of Institutions, Ministries Departments and Agencies for Sustainable Implementation of Socio-economic Projects and Programmes in the Country. United Nations Office of Outer Space Affairs. NASDRA HQ, Obasanjo Space Centre, Lugbe, Abuja - Nigeria. https://www.unoosa.org/documents/pdf/psa/activities/2017/ GrazSymposium/presentations/Thursday/Presentation3.pdf (Last accessed May 19, 2021).

29. Agboola OA. Space System and Engineering in Africa: Nigeria as a Case Study. In the 4th African Leadership Conference on Space Science and Technology for Sustainable Development-ALC 2011 (Building a Shared Vision for Space in Africa). Mombasa, Kenya, September 26-28, 2011.

30. Gbadebo 00. Crude Oil and the Nigerian Economic Performance. Closing Institutional Gaps through Academic Research Management System and Implication in Nigeria, 2008. Paper Presentation to Department of Economics and Development Studies, College of Business and Social Science, Covenant University. Ota, Ogunstate, Nigeria, 2008. http:/logbus.ru/files/ogbus/eng/ authors/Odularo/Odularo_1.pdf (Last accessed May 19, 2020). 
31. Rabiu B. Space Unites the World. World Space Week. National Space Research and Development Agency, Obasanjo Space Centre, Abuja, Nigeria, October 10, 2018.

32. The Centre for Basic Space Science. https://www.nasrdacbss.com (Last accessed July 12, 2019).

33. The Centre for Atmospheric Research. https://carnasrda.com (Last accessed July 12, 2019).

34. Awosanya Y. Nigerian Start-ups raised $\$ 178$ million in 2018. Find out how they did. 2019. https://techpoint.africa/2019/02/11/nigerian-startups-funding-report (Last accessed July 12, 2019).

35. Space Club Obafemi Awolowo University. Astronomers Without Borders. https://astronomerswithoutborders.org/my-awb/our-current-affiliates/network .html?id=610 (Last accessed July 12, 2019).

36. Space Club Obafemi Awolowo University Aerial Vehicle UAV or Drone. YouTube. https://www.youtube.com/watch?v=TalUlc_TnZU (Last accessed July 12, 2019).

37. Lanre A, Olalekan A. Nigeria Space Program. National Space Research and Development Agency (NASRDA). NASDRA HQ, Obasanjo Space Centre, Lugbe, Abuja - Nigeria. https://www.researchgate.net/publication/264894044_Nigeria_ Space_Programs (Last accessed May 19, 2021).

38. National Space Research and Development Agency. https://en.wikipedia.org/ wiki/National_Space_Research_and_Development_Agency (Last accessed July 12, 2019).

39. Okafor RG, Onwumere JUU. Issues and challenges in enhancing efficient entrepreneurial accounting education in Nigerian universities. Dev Ctry Stud. 2012;2:220-227.

40. Andela's latest $\$ 100$ million funding round is led by a former US Vice President. https://qz.com/africa/1531075/andela-raises-100-million-series-dround-from-al-gore-led-vc/ (Last accessed July 12, 2019).

41. Dada P. Herdsmen kidnap woman, stepson in Ondo, demand N10million ransom. Punch Nigeria, 2019. https://punchng.com/herdsmen-kidnap-woman-stepsonin-ondo-demand-n10million-ransom/ (Last accessed July 12, 2019).

42. Fulani Herdsmen have turned Ondo into Unsafe Place as they Kidnap, rape us, Ondo Women Lament. Sahara Reporters, New York. http://saharareporters .com/2019/05/24/fulani-herdsmen-have-turned-ondo-unsafe-place-they-kidnaprape-us-ondo-women-lament (Last accessed July 12, 2019).

43. Martin G. NewSpace: The "Emerging" Commercial Space Industry. SSP14. NASA Ames Research Centre, 2014. Mountain View, California, United States. https://ntrs.nasa.gov/api/citations/20140011156/downloads/20140011156.pdf (Last accessed May 19, 2021).

44. Global Space Industry Dynamics. Research Paper for Australian Government, Department of Industry, Innovation and Science by Bryce Space and Technology, LLC. https://www.industry.gov.au/sites/default/files/2019-03/global_space_ industry_dynamics_-_research_paper.pdf (Last accessed May 19, 2021).

45. Selding P. India' ANTRIX says it can handle foreign launch competition, but domestic competitions could be tough. https://www.spaceintelreport.com/ indias-antrix-says-it-can-handle-foreign-launch-competition-but-domesticcompetitors-could-be-tough/ (Last accessed July 12, 2019).

46. Mokkil V. Minnie Vaid on the women of ISRO: 'Remarkable stories of grit and determination. June 15, 2019. https://www.thehindu.com/society/minnie-vaidon-the-women-of-isro-remarkable-stories-of-grit-and-determination/article 27910839.ece (Last accessed July 12, 2019).

47. Regidi A. How does ISRO' GSLV Mk III fare against some of the worlds' most powerful rockets? July 12, 2019. https://www.firstpost.com/tech/science/howdoes-isros-gslv-mk-iii-fare-against-some-of-the-worlds-most-powerful-rockets6841311.html (Last accessed July 12, 2019).

48. ISRO annual report 2018-19. Indian Department of Space, 2019. https:// www.isro.gov.in/sites/default/files/annualreport2018-19.pdf (Last accessed May 19, 2021).

49. Poddar D. Nothing Quite Like Model Rocketry to Bring Spaceflight to the People. June 26, 2019. https://thewire.in/space/model-rocketry-isro-spaceflight-nasa (Last accessed July 12, 2019).

50. Rockeeters India. July 5, 2019. https://youtu.be/FGeVOuEg7AQ (Last accessed July 12, 2019).
51. Ravikumar S. India's space start-ups ignite investor interest. June 23, 2019. https://in.reuters.com/article/space-exploration-india-funding/indias-spacestartups-ignite-investor-interest-idINKCN1T004C (Last accessed July 12, 2019).

52. Henry C. Indian start-up Bellatrix Aerospace raises \$3 million. June 21, 2019. https://spacenews.com/indian-startup-bellatrix-aerospace-raises-3-million/ (Last accessed July 12, 2019).

53. DO India Online. How ISRO is Encouraging Start-ups and Entrepreneurs in India. June 3, 2019. https://www.dqindia.com/isro-encouraging-startupsentrepreneurs-india/ (Last accessed July 12, 2019).

54. Prasad N. How ISRO can help satellite launch start-ups tap a billion-dollar (and growing) market. June 2, 2019. https://theprint.in/science/how-isro-canhelp-satellite-launch-startups-tap-a-billion-dollar-and-growing-market/243219/ (Last accessed July 12, 2019).

55. Sharma V. Commercialization of the Indian Small Satellite Industry. May 2019. http://interactive.satellitetoday.com/via/may-2019/commercialization-of-theindian-small-satellite-industryl (Last accessed July 12, 2019).

56. Prasad N. India plans to have a space station of its own by 2030: Here' what we expect. July 9, 2019. https://www.firstpost.com/tech/science/india-plansto-have-a-space-station-of-its-own-by-2030-heres-what-we-can-expect6825141.html (Last accessed July 12, 2019).

57. Garretson P. OPINION: The first duty of a Space Force is to protect space commerce. June 21, 2019. https://www.politico.com/story/2019/06/21/opinionspace-force-commerce-1374229 (Last accessed July 12, 2019).

58. Sasibhushan R. New Space and India. June 24, 2019. http://www.indian defencereview.com/news/new-space-and-india/ (Last accessed July 12, 2019).

59. Joshi M. India Has a Long Way to Go Before it Can Use Space for Modern Warfare. June 16, 2019. https://thewire.in/space/india-space-military-isroinsat (Last accessed July 12, 2019).

60. Sharma R. ISRO has realised Sarabhai's vision of using space technology to help the common man. April 19, 2019. https://www.downtoearth.org.in/ news/science-technology/isro-has-realised-sarabhai-s-vision-of-using-spacetechnology-to-help-the-common-man-64077 (Last accessed July 12, 2019).

61. Deloitte. Overview of Indian Space Sector 2010. 2010. http://www.cii.in/ webcms/Upload/Antrix-CII-Deloitte\%20report\%20on\%20Indian\%20Space\%20 Sector\%202010.25Aug 102.pdf (Last accessed July 12, 2019).

62. Lambert T. A short history of Morocco. http://www.localhistories.org/morocco .html (Last accessed July 12, 2019).

63. World Monument Funds. Sijimassa. https://www.wmf.org/project/sijilmassa (Last accessed July 12, 2019).

64. The World Factbook. Morocco, economy overview, CIA. https://www.cia.gov/library/publications/the-world-factbook/geos/mo.html (Last accessed July 12, 2019).

65. Invest in Morocco-7 top reasons. http://www.invest.gov.ma/?lang=enctld=3 (Last accessed July 12, 2019).

66. Bazza T. Morocco's Thriving Aeronautic Industry Attracts International Interest. October 6, 2018. https://www.moroccoworldnews.com/2018/10/ 254695/moroccos-thriving-aeronautic-industry-attracts-international-interest/ (Last accessed August 1, 2019).

67. Morocco World News. Boeing VP: Morocco Strengthens Its Position as Gateway to Africa. https://www.moroccoworldnews.com/2016/12/202875/boeing-vpmorocco-strengthens-position-gateway-africa/ (Last accessed August 1, 2019).

68. Mullan C. Aerospace Cities of the future 2016/2017: the winners. https:// www.fdiintelligence.com/Sectors/Aerospace/Aerospace-Cities-of-the-Future2016-17-the-winners (Last accessed July 12, 2019).

69. Doing Business 2019: Economic Profile Morocco. https://www.doingbusiness .org/content/dam/doingBusiness/country/m/morocco/MAR.pdf (Last accessed May 19, 2021).

70. Doing Business 2020: Ranking of the African and Middle Eastern countries. Atlas Mag. https://www.atlas-mag.net/en/article/doing-business-2019-ranking-ofthe-african-and-middle-eastern-countries (Last accessed May 19, 2021).

71. World Economic Forum. Africa Competitiveness 2017. http://reports .weforum.org/africa-competitiveness-report-2017/competitiveness-ranking/ \#series=GCl.A.02 (Last accessed July 12, 2019). 
72. UNOOSA. Committee on the Peaceful Uses of Outer Space: Membership Evolution. http://www.unoosa.org/oosa/en/ourwork/copuos/members/evolution.html (Last accessed July 12, 2019).

73. Temsamani R. Space activities and space policy in Africa Social, economic and legal aspects Case of Morocco. http://www.unoosa.org/documents/pdf/hlf/ HLF2017/presentations/Day1/Session_2/Presentation8.pdf (Last accessed July 12, 2019).

74. Centre Royal de Télédétection Spatiale (CRTS) - The Royal Centre for Remote Sensing. Angle Avenue Sanawbar et Avenue Allal El Fassi - quartier Hay Riad Rabat 11000 Rabat MOROCCO. https://www.crts.gov.ma/Royal\%20Centre\%20 for\%20Remote\%20Sensing (Last accessed July 12, 2019).

75. Ayetey JS. Why Ghana's space law can't be too restrictive as country looks to expand space agenda. August 14, 2018. https://www.cnbcafrica.com/zdnl-mc/ 2018/08/14/why-ghanas-space-law-cant-be-too-restrictive-as-country-looksto-expand-space-agenda/ (Last accessed July 10, 2019).

76. Drones set to deliver blood and medical supplies to Ghana's hospital. December 13, 2018. https://www.theguardian.com/global-development/2019/ apr/25/medical-delivery-drones-cleared-for-takeoff-in-ghana-zipline (Last accessed July 7, 2019).

77. Sumah K. How can African nations effectively develop a space industry? Positioning Ghana using the dual double diamond model. New Space. 2019; 7(3):179-189.

78. Ghana Launches its first Satellite into space. June 7, 2017. https:// www.bbc.co.uk/news/world-africa-40538471 (Last accessed July 2, 2019).

79. Asabere BD, Gaylard M, Horellou C, Winkler H, Jarrett T. Radio astronomy in Africa: the case of Ghana. arXiv preprint arXiv:1503.08850. March 30, 2015.

80. Is science starting to oil the wheels of Ghana's development? 2017. http:// www.unesco.org/new/en/media-services/single-view/news/is_science_starting_ to_oil_the_wheels_of_ghanas_developme/ (Last accessed May 19, 2021).

81. Mbewa DO. Ghana selected to host AfCFTA secretariat. July 6, 2019. https:// africa.cgtn.com/2019/07/06/ghana-selected-to-host-afcfta-secretariat/ (Last accessed July 10, 2019).

82. Ghana is the star in IMF's 2019 Economic Growth Forecast. April 13, 2019. https://businessghana.com/site/news/business/185314/Ghana-is-the-star-inIMF-s-2019-Economic-Growth-Forecast (Last accessed June 14, 2019).

83. Cho D-S, Moon H-C, Kim M-Y. Does one size fit all? A dual double diamond approach to country-specific advantages. Asian Bus Manage. 2008;8(1):83-102.

84. Foy H. Moving towards a Ghana Space Agency. Summer 2013. https:// africsis.org/wp-content/uploads/bsk-pdf-manager/Article-moving-towards-aghana-space-agency_17.pdf (Last accessed May 30, 2019).

85. Bosma N, Kelley D. Global Entrepreneurship Monitor: 2018/2019 Global Report, Babson Park. Global Entrepreneurship Research Association, 2019. ISBN: 978-19160178-0-1. Gráfica Andes, Chile. https://www.gemconsortium.org/file/ open?fileld=50213 (Last accessed May 19, 2021).

86. International cooperation in the peaceful uses of outer space: activities of Member States, A/AC.105/1189/Add.2. 2019. http://www.unoosa.org/oosa/en/ oosadoc/data/documents/2019/aac.105/aac.1051189add.2_0.html (Last accessed August 12, 2019).

87. Polansky J, Cho M. Classification of countries worldwide according to satellite activity level. Trans Jpn Soc Aeronaut Space Sci Aerosp Technol Jpn. 2016;14:Pv_7-Pv_16.

88. Rayan I. Space reasearch for Sutainable Development in Sudan. Space Research Centre, University of Khartoum, Sudan. http://www.unoosa.org/documents/pdf/hlf/ 1st_hlf_Dubai/Presentations/90.pdf (Last accessed July 12, 2019).

89. Baratoux D, Chennaoui-Aoudjehane $H$, Gibson $R$, Lamali A, Reimold WU, Sapah MS, Chabou MC, et al. The state of planetary and space sciences in Africa. EOS Earth Space Sci News. 2017;98(11):16-23.

90. Thouraya SC. Space activities in Tunisia. 2010. http://www.unoosa.org/pdf/ pres/stsc2010/tech-05.pdf (Last accessed July 12, 2019).

91. Space in Africa: Overview of the Tunisian Space Industry, 2018. https://africanews .space/overview-of-the-tunisian-space-industry/ (Last accessed July 12, 2019).

92. Space in Africa: Towards a tunisian national space strategy, 2018. https:// africanews.space/towards-a-tunisian-national-space-strategy/ (Last accessed July 12, 2019).
93. Mierag Space Technologies Company. https://www.mieragspace.com/ (Last accessed July 12, 2019).

94. Haggar Group, ICT Business. https://www.haggargroup.ae/businesses/ict/ (Last accessed July 12, 2019).

95. Sudatel participates in the successful launch for Arabsat 6A Satellite, African News Satelite. Teletimes International Media. April 16, 2019. https://teletimesinternational .com/2019/sudatel-participates-in-the-successful-launch-for-arabsat-6a-satellite/ (Last accessed July 12, 2019).

96. BRICS- Brazil, Russia, India, South Africa, Ministry of Foreign affairs. http:// www.itamaraty.gov.br/en/politica-externa/mecanismos-inter-regionais/7505brics-brazil-russia-india-china-south-africa (Last accessed July 12, 2019).

97. New Developmental Bank (NDB): Building Sustainable Future. Sandown, Sandton, South Africa. (Last accessed May 19, 2021) https://www.ndb.int/ (Last accessed May 19, 2019).

98. African Union. About the Africa Union. https://au.int/en/overview (Last accessed July 12, 2019).

99. African Developmental Bank (AfDB) Group, HO Abidjan, Côte d'Ivoire. https:// www.afdb.org/en (Last accessed July 12, 2019).

100. African Development Bank. Distribution of Voting Power by Executive Director Statement of Voting Power as at 31 December 2014. https://www.afdb.org/ fileadmin/uploads/afdb/Documents/Boards-Documents/statement_of_voting_ power_as_at_31_december_2014.pdf (Last accessed July 12, 2019).

101. Regional Centre for Remote Sensing of North African States. http://www .crtean.org.tn/en/ (Last accessed July 12, 2019).

102. United Nations Office for Outer Space Affairs. Committee on the Peaceful Uses of Outer Space: Observer Organizations. http://www.unoosa.org/oosa/ en/ourwork/copuos/members/copuos-observers.html (Last accessed July 12, 2019).

103. Space In Africa: Reports, 2019. https://africanews.space/reports/ (Last accessed October 12, 2019)

104. Kazeem Y. A new space agency signals Africa's focus on harnessing geospatial data. Quartz Africa, February 15, 2019. https://qz.com/africa/1550551/egyptto-host-african-space-agency/ (Last accessed July 12, 2019).

105. United Nations Office for Outer Space Affairs. Committee on the Peaceful Use of Outer Space: Membership Evolution. http://www.unoosa.org/oosa/en/ ourwork/copuos/members/evolution.html (Last accessed July 12, 2019).

106. United Nations Office for Outer Space Affairs. Status of International Agreements relating to activities in outer space as at 1 January 2019, United Nations treaties. April 1, 2019. http://www.unoosa.org/documents/pdf/spacelaw/treatystatus/ AC105_C2_2019_CRP03E.pdf (Last accessed July 12, 2019).

Address correspondence to: Oyedamola A. Asiyanbola Skolkovo Institute of Science and Technology Bolshoy Boulevard 30, bld. 1 Moscow 121205 Russia Federation

E-mail: oyedamola.asiyanbola@skoltech.ru

Rayan Imam

Politecnico di Torino

Department of Electronics and Telecommunications Corso Duca degli Abruzzi, 24 10129 Turin Italy

E-mail: rayan.imam@spacegeneration.org 